\title{
The Divergence of Bank Lending Rates from Policy Rates After the Financial Crisis: The Role of Bank Funding Costs 1
}

\author{
Anamaria Illes ${ }^{\mathrm{a}}$, Marco Lombardi ${ }^{\mathrm{a}}$ and Paul Mizen ${ }^{\mathrm{b}}$ \\ a Bank for International Settlements, Basel \\ b School of Economics, University of Nottingham
}

Januaruly $2018 \underline{2019}$

\begin{abstract}
After the global finance crisis, policy rates were cut to near-zero levels, yet, bank lending rates did not fall as much as the decline in policy rates would have suggested. If the crisis represents a structural break in the relationship between monetary policy and lending rates, how should central banks view the post-crisis transmission? This poses a major puzzle for monetary policymakers. Using a new weighted average cost of liabilities to measure banks' effective funding costs we show a model of interest rate pass-through with dynamic panel data methods solves this puzzle, and has many other advantages over traditional approaches. It confirms central banks should focus on the cost and composition of bank liabilities, as many are now doing, to better understand and steer the dynamics of lending rates.
\end{abstract}

JEL: E43, E52, G21

Keywords: lending rates, policy rates, panel cointegration, financial crisis

\footnotetext{
${ }^{1}$ The views are those of the authors and not necessarily those of the Bank for International Settlements. We thank two anonymous referees as well as commentators from the European Central Bank, the European Commission and the central banks of Austria, Belgium, France, Germany, Ireland, the Netherlands, Norway, Spain and the United Kingdom the MMF conference, Cardiff and the International Association for Applied Econometrics conference, University of Milan-Bicocca (Italy), Milan. Specifically we acknowledge comments from Anindya Banerjee, Jef Boeckx, Claudio Borio, Josep Carrion-i-Silvestre, Andrea Cipollini, Jonathan Crook, Hans Dewachter, Markus Eberhardt, Gabriel Fagan, Leonardo Gambacorta, Stefan Gerlach, Rashmi Harimohan, Boris Hofmann, Sarah Holton, Michael McLeay, Dubravko Mihaljek, Adrian van Rixtel, Hyun Song Shin, Ron Smith, Allan Timmerman, Oreste Tristani, Kostas Tsatsaronis, Philip Turner, Philip Vermeulen, Martin Weale, Raf Wouters and Garry Young. Errors remain the responsibility of the authors. Paul Mizen acknowledges financial support from the British Academy-Leverhulme Trust under grant number SG142999.
} 


\begin{abstract}
After the global finance crisis, policy rates were cut to near-zero levels, yet, bank lending rates did not fall as much as the decline in policy rates would have suggested. If the crisis represents a structural break in the relationship between monetary policy and lending rates, how should central banks view the post-crisis transmission? This poses a major puzzle for monetary policymakers. Using a new weighted average cost of liabilities to measure banks' effective funding costs we show a model of interest rate pass-through with dynamic panel data methods solves this puzzle, and has many other advantages over traditional approaches. It confirms central banks should focus on the cost and composition of bank liabilities, as many are now doing, to better understand and steer the dynamics of lending rates.
\end{abstract}

\title{
1. Introduction
}

The global financial crisis prompted central banks in many countries to cut policy rates to near zero levels after the Lehman collapse in September 2008. Based on the pre-crisis relationship between bank lending rates on mortgages or loans to businesses with policy rates, it would have been reasonable to expect lending rates to have fallen by similar amounts. Yet lending rates did not fall that much, and in some vulnerable European countries they actually rose (Von Borstel et al., 2016, ECB 2016, Hristov et al. 2016). In addition, the margins over policy rates widened as policy rates fell (see Graph 1)..$^{2}$ Inevitably the question has been raised by academics and policy makers whether banks were taking advantage of the low interest rate environment by failing to pass on lower rates to loans. ${ }^{3,4}$ A related question is whether a structural break has occurred in the relationship between policy rates and lending rates set by banks requiring a re-evaluation of the determinants of lending rates. Central banks now puzzle over whether the transmission between policy actions and lending rates needs to be revisited in the light of an apparent disconnect between the two (see ECB, 2012; Beirne, 2012; ECB, 2013; Hristov et al., 2016; Von

\footnotetext{
${ }^{2}$ Comparing the average margins on short-term and long-term loans to small business for nine Euro area countries, Denmark and the United Kingdom in the pre-crisis (January 2003 - August 2008) and post-crisis period (September 2008 - April 2014) shows that they rose by $19.5 \%$, while margins on short-term and long-term mortgage loans rose by $41.8 \%$ and $37.5 \%$ respectively.

${ }^{3}$ For example, Arestei and Gallo (2014) argue that since the financial crisis greater risk and high volatility has decreased the influence of policy rates (or market rates which they use as a proxy for policy rates) over lending rates. They then conclude that this reflects 'opportunistic behaviour by banks, which [have taken] advantage of the reduction in official interest rates without transferring these benefits to borrowers'. (p292, Arestei and Gallo, 2014).

${ }^{4}$ In Ireland, Michael Noonan, the Finance Minister, called in the chief executive officers of the major Irish Banks to investigate concerns about relatively high rates being charged to borrowers in certain segments of the mortgage market (Irish, Times, 14 September 2015)
} 
Borstel et al., 2016). The behaviour of bank lending rates during a period when the monetary stance was exceptionally loose but sovereign and credit risk were elevated (Beirne and Fratzscher, 2013) has now become a major policy issue (see Goggin et al. 2012; Albertazzi et al. 2014; Arnold and van Ewijk, 2014; Darracq-Paries et al. 2014; De Sola Perea and Van Nieuwenhuyze, 2014; Holton and Rodriguez, 2015), not least because many countries in Europe have a high degree of bank dependence. ${ }^{5}$

In this paper, we present evidence that a new weighted average cost of liabilities measure reflecting the actual funding costs of banks displays a more stable relationship with bank lending rates than the corresponding relationship with policy rates. It does not break down after the crisis, and explains why lending rates remained high when policy rates fell. This has refocused attention on the cost and composition of bank funding as a means to understand interest rate pass-through (ECB, 2015; ECB, 2016) and to explain persistent real interest differentials that reinforce cyclical differences in monetary transmission through the investment channel (European Commission, 2016).

The main contribution of the paper is to focus attention on the whole range of liabilities that banks use to acquire funds (see Adrian et al. 2013; Turner, 2013). We do this by comparing the response of new business lending rates to the weighted-average cost of liabilities and separately to the individual components that are used in its construction. ${ }^{6}$ Most other studies, as Von Borstel et al. (2016) note, 'rely on money market rates such as the EONIA (Euro OverNight Index Average) as a measure for monetary policy, neglecting the effects of unconventional monetary policy'. In this paper, we aim to correct this shortcoming by looking at all types of funding and their associated costs. To be clear about our methods, we multiply the cost of liabilities by the corresponding share of the liabilities on the banks' balance sheets (excepting equity for reason given later) in every period to create a marginal cost of funds that can be related to the new business rates offered by banks to firms and households.

We devote the first part of the paper to careful construction of the weights using information form the banks' balance sheets. The new marginal cost of funds we construct can vary over time as weights or funding costs change. We then investigate the relationship between lending rates on new business, our new marginal cost of funds and policy rates over the period 2003 - 2017 for European countries in the euro area (Austria, Finland, France, Germany, Ireland,

\footnotetext{
${ }^{5}$ Bank loans comprise some 50 percent of loans to firms and 90 percent of loans to households in Europe according to Von Borstel et al (2016).

${ }^{6}$ The weighting schemes adopted average across liability types, and not over time.
} 
Italy, the Netherlands, Portugal and Spain) and those outside of the euro area (Denmark and the United Kingdom) using state-of-the-art non-stationary dynamic heterogeneous panel models initially developed by Peseran and Smith (1995) and Peseran, Shin and Smith (1999), but more recently extended by Pesaran (2006) and Chudik and Pesaran (2015). Previous panel approaches to model interest rate pass-through c.f. Sorensen and Werner (2006), and Hristov et al. (2016) found evidence of incomplete pass-through but without taking into account cross-country dependence between countries as we do, which is likely to be more important in the most recent period of financial and sovereign debt crises (see Von Borstel et al., 2016). Von Borstel et al. (2016) provide a factor-augmented VAR, which assesses the responses of a large number of country-specific interest rates and spreads reflecting banks' funding risks and mark-ups over bank funding costs.

Our paper establishes that the lending rates, policy rates and funding costs co-move in the period up to the crisis, but the relationship breaks down after extending the sample with postcrisis data. This relationship cannot be restored by simply allowing for structural breaks at the time of the crisis. Yet the relationship between lending rates and funding costs is stable for the full sample, spanning the pre-crisis and post-crisis periods, supporting the pass-through findings by Holton and Rodriguez (2015) and Von Borstel et al. (2016). ${ }^{7}$ Tests of robustness reveal a stable relationship with some small reduction in the reported pass-through coefficients by about 10 percent as we progressively extend sample into the post-crisis period, and a more substantial reduction by about 33 percent in the speed of adjustment. We are also able to identify stable relationships between the lending rates and some individual components of the WACL, which shed light on the channels of monetary transmission for different lending rates. These findings have important implications for central banks' understanding of the monetary transmission mechanism and regulation of banks in the post crisis period, not least because they contribute to persistent real interest differentials (European Commission, 2016).

\footnotetext{
${ }^{7}$ Von Borstel et al (2016) also construct an average measure of bank funding costs, which is then employed to assess the transmission of monetary policy shocks to lending rates in a FAVAR framework in two samples, a pre-crisis sample and a sovereign debt crisis sample excluding the global financial crisis. They include in their FAVAR a monetary policy rate a dummy variable for announcements of unconventional monetary policy factors representing country-level bank lending rates and decompositions of the spreads over risk free rates to allow for sovereign and bank specific risk and mark ups. They conclude that monetary transmission did not change (during the sovereign debt crisis versus the pre-crisis period), but neither did it reduce the gap between bank loan rates and funding costs, which remained elevated. Our paper seeks to establish the stability of the connection between funding costs and lending rates for 11 euro area and non-euro area countries, while theirs seeks to compare the impact of conventional and unconventional monetary policy in the euro area on several different loan-policy spread components using a wider array of variables in two sample periods (pre financial crisis and the sovereign debt crisis).
} 
How do we explain these results? Our contention is that while policy rates were a reasonable proxy for funding costs in the pre-crisis period, because liquidity and counterparty risks were low and stable, they ceased to be a good proxy for funding costs once the financial crisis occurred (see Goggin et al. 2012; Albertazzi et al 2014; Arnold and van Ewijk, 2014; De Sola Perea and Van Nieuwenhuyze, 2014; Holton and Rodriguez, 2015)..$^{8}$ The policy rate is not an accurate representation of the marginal cost of funds for banks after 2007 when the cost of funds from the impaired interbank market diverged from policy rates. Since the global financial crisis larger risk premia associated with securities issued by banks and interbank borrowing have raised the cost of market funding for banks (see ECB, 2009, 2010a,b; Zoli, 2013) illustrated by the divergence of bond yields across borders, which has reversed the trend of lower and more similar rates since the late 1990s (ECB, 2012). The sovereign debt crisis limited the ability of governments to recapitalise their banks as their own debt increased, widening bond spreads further (ECB, 2012). In addition, mark-downs on deposit rates, which would normally be below policy rates, have been constrained by the zero lower bound. On top of that, there has been greater competition among banks for term deposits, which further raised these rates, as higheryield assets such as fixed-term securities issued by governments have increasingly been seen as substitutes for low-yielding deposits by savers (see Darracq-Paries et al. 2014, and Von Borstel et al., 2016). Some of these effects have been addressed by targeted long-term refinancing operations (TLTROs in the Euro area and Funding for Lending in the UK) and asset purchase programmes (APP and QE in the euro area and the UK respectively) as discussed in Churm and Radia (2012) and ECB $(2015,2016)$.

There are significant implications for monetary policy operation and transmission from our findings as greater attention is given to the cost and composition of bank funding as a means to understand interest rate pass-through (ECB, 2016). The implications of financial fragmentation contribute to different nominal lending rates, even in a common monetary area, and these may create persistent real interest differentials that reinforce cyclical differences in monetary transmission through the investment channel (European Commission, 2016). By understanding the components of bank funding costs that are elevated, it is also possible for policymakers to focus non-standard monetary policy on those markets to lower funding costs (ECB, 2015).

\footnotetext{
${ }^{8}$ The empirical literature on pass-through represented by Borio and Fritz (1995), De Bondt (2002, 2005), Ehrmann et al (2003) Hofmann and Mizen (2004) has used policy rates or money market rates to explain short-term lending rates, and has used longer-dated, often maturity-matched yields on securities to explain longer-term loans. An exception in this respect is De Bondt et al. (2005) which refers to the cost of funding measured by short-term and long-term market rates, and our paper follows in that tradition, but uses information from bank balance sheets to structure the funding costs.
} 
The rest of the paper is organised as follows. In Section 2, we present a simple model to frame our results. Section 3 discusses the construction of the weighted average cost of liabilities, including details on the data sources and their characteristics. This new measure of average funding costs is the cornerstone of our empirical analysis. In Section 4 we show that the relationship between lending rates and policy rates breaks down. Section 5 shows the relationship to funding costs is stable and robust. Section 6 investigates the dynamic aspects of the relationship between monetary policy and bank funding costs. Section 7 discusses the policy implications and concludes.

\section{An Illustrative Model and Some Background Literature}

To set our empirical analysis in a theoretical framework, we consider a simple illustrative model based on Berlin and Mester (1999) [hereafter BM], which considers the contracting relationship between a firm and a bank. The core feature of the model is the setting of lending rates subject to the liability structure of the bank. It shows that lending rates should be related to the liability structure of the bank, but it does not extend this observation to more than market funds and deposits. We argue in this section that the set of liabilities should be greatly enlarged to account for the diverse sources of funds that banks use to fund their activities.

In BM, the decisions of the firm and the bank are made over two periods, 0 and 1 . The state of the world in period 1 is unknown to the bank or the firm, and it can be good $(g)$ or bad $(b)$ : $s \in\{g, b\}$. The probability of a good period is $p$, and of a bad period (1- $p$ ). Firms have positive earnings in good times, $E_{g}>0$, and no earnings in bad times, $E_{b}=0$. The state is revealed at the start of period 1 and the economic conditions are observable to all parties. It is assumed that the firm must borrow from the bank to invest, or liquidate some of its assets $A(k)$, where $k \in[0, K]$; this reduces the future value of the firm in order to generate liquid assets in the present.

The BM bank has a representative liability structure: deposits and market funds are held in proportions $w$ and $(1-w)$. Certain restrictions are assumed: the cost of funding is state dependent and higher in bad times $\left(C_{b}>C_{g}\right)$; the expected value of market funds exceeds the cost of core deposits, the cheapest available source of funding. Shares of certain liabilities can be zero. Further assumptions ensure earnings in good times cover the returns to depositors $\left(E_{g}>C_{g}\right)$, although in bad times liquidation is required, since $C_{b}>0$. The capital, $\mathrm{K}$, is always larger than the weighted average cost of liabilities (1) even in the bad state of the world. These assumptions ensure that liquidation levels in good times are zero, and in bad times are just sufficient to cover the cost of liabilities for the bank., $L_{b}$. 
The BM bank and firm both maximise profits, defined in each case as revenue minus costs in each state of the world times the probability that each state of the world will occur. Thus

$\Pi^{f}=p\left[E_{b}+k_{b}+A\left(k_{b}\right)-r_{b}\right]+(1-p)\left[E_{g}+k_{g}+A\left(k_{g}\right)-r_{g}\right]$

$\Pi^{b}=p r_{b}^{l}+(1-p) r_{g}^{l}-\left[p L_{b}+(1-p) L_{g}\right]$

where $r_{s}^{l}$ is the lending rate of interest for $s \in\{b, g\}$, and $k_{s}$ is the liquidation level. The bank faces Bertrand competition in the loan market, treats its liability structure as given in the present period, and maximises its own profits, which results in a lending rate equal to the weighted average cost of liabilities defined in each state of the world 9 :

$r_{s}^{*}=L_{s}$

In this framework, pass-through occurs between the weighted average cost of liabilities and the loan rates, not the policy rate and loan rates. Lending rates will be lower in good times than in bad times because the cost of funds will be lower in good times than bad times, but the passthrough in each state of the world will be complete, since $\frac{d r_{s}^{*}}{d L_{s}}=1$ for $s \epsilon\{b, g\}$. However, in the transition from model to testable hypotheses, BM admit that a bank may protect its borrowers (making a smaller increase to its markup) during bad times if it has a higher level of core deposits, ensuring that the pass-through is less than complete. This hypothesis is upheld, breaking the full pass through assumption, but this does not break the connection between lending rates and the cost of liabilities of the bank.

The modelling framework described above stands in contrast with the assumptions behind the majority of the empirical literature, i.e. that banks obtain funds for short-term lending at contemporary market rates (or policy rates), while longer term lending rates on mortgages or business lending are funded by 5- or 10-year sovereign bond yields (as a proxy for longer term market finance for banks). There is little discussion about deposit rates or the liability structure of banks, despite extensive discussion of pass-through by banks (see Borio and Fritz, 1995; De Bondt, 2002; Ehrmann et al. 2003; Hofmann and Mizen, 2004; De Graeve et al. 2007; ECB, 2009; Kwapil and Sharler, 2010; Kopecky and Van Hoose, 2012; Banerjee et al. 2013; and DarracqParies et al., 2014).

\footnotetext{
${ }^{9}$ In Berlin and Mester (1999) the bank maximises the joint profit then the optimal contract maximises the profit of the firm and the bank, and should ensure that (4) holds when $s=b$, but when $s=g$ then $r_{g}^{*}=\frac{p L_{b}+(1-p) L_{g}-p k_{b}^{*}}{(1-p)}$. This is a
} 'relationship lending' result that causes the relationship between cost of funds and loan rates to differ between good and bad periods. 
With the onset of the global financial crisis, these results have to be re-examined to account for the fragmentation of funding arrangements noted by Arnold and Ewijk (2014), De Sola Perea and Van Nieuwenhuyze, (2014), Darracq-Paries et al (2014) and Holton and Rodriguez (2015). Short-term money market rates on unsecured interbank lending and collateralised repurchase agreements have deviated substantially from policy rates as liquidity and counterparty risk has increased. Moreover, the sovereign bond yields are no longer good proxies for the cost of market finance for banks in the period after the financial crisis. The higher default risk associated with banks in 2007-2009, lower quality of assets and undercapitalization have caused bank bond yields to deviate from sovereign bond yields according to Arnold and van Ewijk (2014), De Sola Perea and Van Nieuwenhuyze, (2014) and Darracq-Paries et al (2014). As yields on senior unsecured bonds issued by banks rose, gross issuance fell to near zero in the vulnerable countries and was replaced by covered bond issuance in other euro area countries (see Van Rixtel and Gasperini, 2013). This intensified in the sovereign debt crisis and the lending costs of these banks rose, particularly in the vulnerable countries (see Zoli, 2013 Albertazzi et al. 2012; and Von Borstel et al., 2015).

All in all, this suggests it is no longer valid practice to take a policy rate, a short-term wholesale market rate or a sovereign bond yield as a proxy for bank funding costs. Instead we suggest the BM model might be generalized to allow for a much wider set of liabilities held by the bank including: deposits, unsecured market funds of various types and maturities that include interbank deposits and bonds, and secured market funds that include covered bonds. We therefore have a weighted average cost of liabilities (WACL) measure defined as:

$L_{s}=C_{s}\left(w_{j}, R_{j}\right)=\sum_{j=1}^{J} w_{j} r_{j s}$

where $j$ indexes the type of liability, with a weight, $w_{j}$, based on the proportional share in total liabilities and the rate of interest $r_{j s}$. Thus we propose to use a WACL concept that would allow for multiple sources of funds, and ensure that lending rates respond to the weighted average of these costs of liabilities not just to market or deposit rates, or any other arbitrarily selected rate.

\section{Bank Funding Costs}

An important contribution of this paper is the construction of a weighted average cost of liabilities (WACL) as an alternative benchmark for bank funding costs in each country. There are parallels between our approach and De Bondt et al. (2005), who argue that banks apply a markup with respect to a "cost" that depends on short and long-term market interest rates. This section explains how we compiled our measure, while details on data sources are reported in an appendix. The main difference between our approach and De Bondt et al. (2005) is that we use 
the information on the banks' balance sheets to construct our liability measure, while they take a weighted average of short and long rates from the yield curve.

The WACL is a volume-weighted average of the rates at which Monetary and Financial Institutions (MFIs) can obtain finance: $W A C L_{i t}=\sum_{j=1}^{J} w_{i j t} r_{i j t}$, where $r_{i j t}$ are new business rates on the different component liabilities that the banks use to provide funds, and $w_{i j t}$ are the weights on those rates based on the component share in total liabilities for the banks in each country. Taking $i$ to be the country index, $j$ the index of the types of liabilities held by banks, and $t$ the time period, we sum over liabilities to provide an index of the weighted average cost of liabilities for each country $i$ at each point in time $t$. We calculate two sets of WACL based on different maturities: one for the short-term and one for the long-term. We calibrate the short-term measure with a maturity of less than 1-year, whereas the long-term measure reflects maturities of more than 1year, with an average of 5-years.

Our sample covers a total of 11 countries, nine euro area countries and in addition Denmark and United Kingdom. ${ }^{10}$ The data starts in 2003 and goes up to the end of 2017. For the euro area countries, data is obtained from the ECB's Monetary and Financial Institutions Interest Rates (MIR). We used the data from the national central banks in order to complete the database for Denmark and the United Kingdom.

\subsection{Components and weights}

We use two weighting schemes using weights based on a) outstanding stock of liabilities from banks' balance sheets, and b) flows rather than outstanding volumes. Both schemes are used to form weighted averages of interest rates on new transactions in the WACL measure, labelled WACL(stock) and WACL(flow) respectively. The first has the advantage that it draws information on a wider range of components from the bank balance sheets compared to the second, while the second has the advantage that new business rates are combined with changes to volumes to give a truly marginal cost of funds. Ultimately, we rely on the first weighting scheme based on outstanding stock of liabilities and use the second to provide a comparison from the flows. The results show that there similar outcomes in both cases regardless of the weight measure.

It is important to note that the relative proportions of the liabilities used to construct the weights vary from month to month, although the actual adjustment is not particularly fast in comparison to the adjustment of interest rates (discussed below). At the monthly frequency of

\footnotetext{
${ }^{10}$ The rationale for including non-euro area countries is to test whether the issue is shared by more countries, or is just a feature of the monetary union.
} 
our analysis, therefore, weights vary slowly over time. In addition some changes to the weights occur for reasons beyond the control of the banks, such as the emergence of new funding sources i.e. liquidity operations of central banks. This allows us to treat the liability weights as effectively exogenous in our dynamic panel estimates.

The WACL is constructed using five types of liabilities. ${ }^{11}$ Deposit liabilities (in all currencies, and excluding the general government) vis-à-vis the euro area ${ }^{12}$ to MFIs (interbank deposits) and to non-MFIs (deposits of the private non-financial sector) are the largest source of funds. Banks have a substantial deposit base in most countries, so that the first two components account for a large share of funding for lending: over 90 percent of total funding in the short-term and 70 percent of total long-term funding. Deposits from non-MFI sources are the largest component of the funding measure.

Debt securities issued in all currencies in the euro area by the MFIs are reported at maturities up to and over one year. Bond markets are segmented to a large extent on national lines (van Rixtel and Gasperini, 2013) and tend to be influenced in different ways at times of crisis, yields showing substantial spikes. According to Table A1-A4, conventional bonds comprise a small share of short-term funding, while they account for approximately 15-30 percent of funding in the long term. We conclude that these securities are used much more extensively for long-term funding.

Covered bonds data are obtained from Dealogic, and since the majority have a maturity of more than one year, they are used only in long-term funding calculations. The outstanding volumes are not typically large, except for Germany and Spain, but they have grown since the crisis.

Lastly, funding from central bank operations such as the Main Refinancing Operations (MROs) and the Long-Term Refinancing Operations (LTROs) exists only for the euro area countries. Cheap funding given by the ECB in crisis time slightly lowered the funding cost of the MFIs. Van Rixtel and Gasperini (2013) show that Spain and Italy relied most heavily on liquidity

\footnotetext{
${ }^{11}$ These are discussed in greater detail in the data appendix. We exclude funding from equity issuance from the WACL since it accounts for a small percentage of the outstanding balances, and it is arguably not used by banks as a source of regular finance for bank lending, but rather as a structural adjustment (e.g. adjustment of capital ratios in response to regulatory requirements). Besides, Adrian et al. (2013) show that while changes in banks' assets (including loans) and changes in their debt move proportionally, equity remains 'sticky', i.e. it does not adjust when there is a change in assets.

${ }^{12}$ For Denmark and the United Kingdom, we take the country itself as reference area, as opposed to the euro area as a whole.
} 
operations provided by the ECB having borrowed, respectively, €400bn and $€ 277 \mathrm{bn}$ in September 2012.

The alternative WACL(flow) measure is constructed using new deposit data and gross issuance of conventional and covered bonds. We use this to check that our results are not distorted by the use of outstanding amounts to construct the weights.

Tables A1 and A2 in the Appendix provide a summary of the weights averaged over time based on outstanding amounts.

\subsection{Interest rates}

Each type of liability has a matching interest rate, which is always based on new transactions. ${ }^{13}$ For the MFIs deposits to other MFIs we use the interbank money market rates. For the shortterm we use the overnight rates, while for the long-term the 1-year rates. The deposit rate of the non-MFI deposits for the euro area countries is obtained from the ECB MFI interest rate statistics, and is the rate on euro deposits with agreed maturity for the non-financial corporations and households with maturities up to 1 year for the short-term and over 1-year for the long-term. For Denmark and United Kingdom, similar rates have been obtained from the national central banks. Since Denmark reports no breakdown of interest rate by maturity, we use the same rates for both short-term and long-term deposits.

As for the cost of debt securities, we measure the yield on bonds issued by banks as the interest rate swap rate plus a mark-up based on the credit default swap (CDS) rate for the banking sector in each country, using a simple average of available CDS rates for financial institutions in each country. In order to measure the long-term rate we use the 5-year interest rate swap and the 5-year financial CDS while for the short-term the 1-year interest rate swap plus the 1-year financial CDS. The interest rate on covered bonds is obtained from Barclays, which reports the yield to maturity for the outstanding amount of bonds (see the appendix where we plot the data). The rate on central bank operations is the Main Refinancing Rate of the euro area (liquidity operations were only available for banks in the euro area).

The short-term and long-term interest rates are reported in Tables A3 and A4 in the Appendix. These figures indicate one source of the differences between the funding costs for different countries in our sample. When multiplied by the relevant weights they provide the short- or long-term WACL funding costs used in our analysis.

\footnotetext{
${ }^{13}$ This implies both the baseline and the fully marginal WACL rely on the same interest rates.
} 


\subsection{A Comparison between WACL and the policy rate}

WACL funding costs are plotted in Graph 2, together with policy rates. Short-term funding costs followed policy rates very closely in all the countries in our sample, except during the 2003-2004 downturn, while long-term funding costs were higher than policy rates, reflecting a term premium and compensation for risk. After the Lehman bankruptcy, credit risk was re-assessed, and the risk premium jumped upwards. While risk free rates fell as policy rates were reduced, market funding added a larger margin for credit risk than in the pre-crisis period (see Gilchrist and Mojon, 2013, Darracq-Paries et al. 2014). In most countries, this created wider margins between short-term and long-term funding costs, creating a divergence with policy rates in the post-crisis period. This is most evident in the vulnerable countries, Ireland, Italy, Portugal, Spain, but also in the UK, which was more heavily exposed to the effects of the crisis at an early stage, as well as for Austria, whose banks were heavily exposed to Central and Eastern European countries. It is apparent from Graph 2 that there are sharp spikes from 2010Q1 reflecting the higher yields on conventional and, to a lesser extent, covered bonds following the sovereign debt crisis. To some extent, recourse to ECB liquidity cut the cost of funding but the influence was rather small.

\subsection{The comparison between WACL and lending rates}

We now turn to the main subject of our paper: a comparison of the WACL and lending rates offered by MFIs to households and the non-financial corporations. For households we collect from the ECB lending rates on new loans for house purchases (excluding revolving loans), overdrafts and credit card debt for maturities of up to 1-year and over 1-year. For non-financial corporates we collect the lending rates on new loans (other than revolving loans) and overdrafts and credit card debt, for the same breakdown of maturities as above. For Denmark, data are obtained from the national central bank.

We examine separately short- and long-term lending. Graph 3 shows the rates on mortgage lending to households and loans to non-financial corporations for terms of less than one year versus the WACL. The movements in lending rates and funding costs are fairly similar within each country: there is a co-movement between these variables and policy rates. However, in the post-crisis period funding costs diverge from policy rates, and lending rates to households and firms tend to follow more closely the movement of funding costs.

For the long term lending rates (over one year) we see a different pattern that is most evident in the vulnerable countries (Ireland, Italy, Portugal and Spain), and to some extent 
Austria. This can be seen in Graph 4 where the funding costs peaked from 2010-12 and slowly decreased after this period.

\section{Analysis of the Properties of Interest Rates}

4.1 An overview of our approach

There is a long history in econometrics of exploring equilibrium relationships using cointegration analysis (Granger, 1981; Granger 1983; Granger and Weiss, 1983; Engle and Granger, 1987) and error correction models (Phillips, 1957; Sargan, 1964; Davidson et al 1978). This is necessary because series are likely to be integrated, which is likely to show extremely high (spurious) correlation (Granger and Newbold, 1974), simply because a plain correlation analysis would pick up the trending behaviour of both variables. In our context, cointegration pins down the long-run relationships between the lending rates and the WACLs, while recognizing the integrated nature of the data as shown in Table 1.

Our particular methodology, pooled mean group estimation (PMG) can then help determining the pass through coefficient from WACL to lending rates in the data. If we look at short time horizons of one or two months, we may find the variables do not co-move (short-term deviation), but over the longer time horizon, they do co-move. This is especially appealing in our setting, as we cover euro area countries sharing a common monetary policy. More specifically, it seems reasonable to assume that changes in the level of interest rates would eventually transmit to lending rates in all countries, which is enforced by a common long-run relationship. At the same time, however, country-specific structural features, e.g. competition in the banking market, easier access to capital and securities markets 14 are likely to make the transmission uneven in the short run, which is reflected by the use of PMG is a suitable specification since our study covers many countries which over the long run may move in similar ways to each other, but it allows for-differential short-run relationships across countries, and also-differential speed of convergence to the common long-run equilibrium. These differences across countries could reflect some differences in labour or product markets, economic structure, banking system etc. They are reported in Tables 3,4 and 6.15

${ }^{14}$ For example, Fungáčová et al (2014) find that in the euro area the transmission of monetary policy via the bank lending channel is weaker in countries with concentrated market power; while Gambacorta and Mizen (2019). note that greater availability of bank capital and access to securitization dampens the effect of monetary policy shocks.i

${ }^{15}$ We note that it is perfectly possible to use short-term interest rates in long-run equilibrium analysis via cointegration. The short-run on the interest rate refers to the maturity of the instrument (policy rate or security) not the horizon of the relationship. Therefore, a long run 
We note that it is perfectly possible to use short term interest rates in long rum

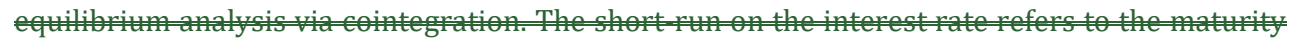

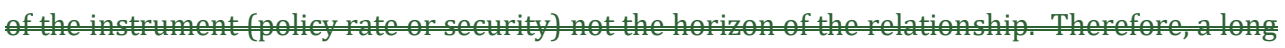
fun relationship (by which we mean a stable cointegrating relationship) could exist between a short term funding cost and ashort term lending rate.

We would not expect pass-through to be perfect in the short-run, but if the long-run passthrough is low, it is a sign that there are serious structural differences between financial markets in these countries. The use of a dynamic model such as PMG helps to distinguish dynamic adjustments (that drive the short-run behaviour of lending rates) from the long-run relationships. It is also conceivable that over periods when there have been significant shocks to financial relationships and the policy response that structural breaks may occur in the data, and we allow for these in our models.

\subsection{Preliminary analysis of the data}

We first test the properties of the interest rates beginning with non-stationarity. We use the Im, Pesaran and Shin (2003) test, with a null hypothesis that no variable in the panel has a unit root. The test statistic is based on the standardised t-bar test statistic based on the (augmented) Dickey-Fuller statistics averaged across the groups, which converges to a standard Normal. Results reported in Table 1 show we comfortably fail to reject the null in all cases, which confirms that the interest rates are all non-stationary. This means that any levels relationships between them should satisfy the requirement of being co-integrated. ${ }^{16}$

relationship (by which we mean a stable cointegrating relationship) could exist between a shortterm funding cost and a short-term lending rate.

\footnotetext{
${ }^{16}$ This can be surprising to economists used to nominal variables such as interest rates and inflation being stationary. However, the literature starting with Klemperer (1987), Hannan and Berger (1991), Neumark and Sharpe (1994) and Cottarelli and Kourelis (1994) suggests that adjustment costs and imperfect competition give banks incentives to adjust their lending or deposit rates sluggishly. Berlin and Mester (1999) appeal to relationship banking to explain persistence in rates over the economic cycle, while Hofmann and Mizen (2004) and Banerjee et al. (2013) imply banks may set rates based on current and forecasts of future money market rates. De Bondt et al (2005) note that banks set loan rates on longer maturity products to minimize interest rate risk and therefore respond sluggishly to changes in short term market rates. For policy rates the persistence is often explained by the policymaking process involving committees that must build consensus around a case for change, and the desire to build credibility by avoiding reversals of rates. In the presence of parameter and model uncertainty (Brainard, 1967), policymakers appear to smooth rates (Goodfriend, 1991; Sack, 2000; Orphanides, 2003).
} 
Many authors have noted that due to trade and financial market integration there are close international interdependences between countries, particularly in a competitive market or a common currency area (Kose et al., 2003, Canova et al., 2007, Pesaran et al., 2007, Canova and Ciccarelli, 2009, 2013). Therefore, we use second-generation CIPS test of panel unit root test due to Pesaran (2007) that allow for cross sectional dependence modelled using cross-sectional means of the levels and differences of the variables. The results reported in Table 1 comfortably fail to reject the null in all cases except two at the $10 \%$ level, based on the same standardised average t-statistic against critical values given in Pesaran (2007).

\subsection{Long-run relationships}

To explore the long run with non-stationary variables in our panel we use the Persyn and Westerlund (2008) panel cointegration test, which makes allowance for cross-sectional dependence. Failure to find cointegration would suggest that there is no long-run relationship between the variables of interest. Defining the relationship between $y_{i t}$, (the lending rate which is the focus of our analysis), and $x_{i t}$, the driver of the lending rate (i.e. the policy rate or the WACL) using the following equation:

$\Delta y_{i t}=\alpha_{i}\left(y_{i, t-1}-\theta_{i} x_{i, t-1}\right)+\sum_{p=1}^{P} \chi_{i p} \Delta y_{i, t-p}+\sum_{q=0}^{Q} \delta_{i q} \Delta x_{i, t-q}+e_{i t}$

We compute two test statistics, $G_{\tau}$ and $P_{\tau}$, for each lending rate. The null and alternative hypotheses are formulated as

$\mathrm{H}_{0}: \alpha_{i}=0$ versus $\mathrm{H}_{1}: \alpha_{i}=\alpha<0$ for all $i$, which can be interpreted as a null of no cointegration and a rejection of the null as evidence of cointegration for the panel as a whole.

$\mathrm{H}_{0}: \alpha_{i}=0$ versus $\mathrm{H}^{\mathrm{G}} 1: \alpha_{i}<0$ for at least some $i$, which can be interpreted as a null of no cointegration and a rejection of the null as evidence of cointegration for at least one of the cross-sectional units.

We first apply these tests to the relationship between four separate lending rates and policy rates and the results are mixed for the full sample. The test statistics are reported in Table 2 and the null hypothesis of no cointegration is rejected only in a few cases. The $G_{\tau}$ test indicates one out of four rejections, and the $P_{\tau}$ test two out of four rejections using data over the full sample. This implies the relationship is less stable than for the period prior to the global financial crisis, where we find that the null hypothesis of no cointegration is rejected all cases but one. We can interpret this as evidence of a change in the relationship at around the time of the financial crisis.

Table 2 also reports cointegration tests for WACL(stock), WACL(flow) and the four different lending rates. Results for the WACL(stock) measure rejects the null of no cointegrating relationship under $G_{\tau}$ and $P_{\tau}$ tests with no exceptions. For WACL(flow) we find the same result, except for short-term lending to businesses, where we cannot reject the null of no cointegration. 
We conclude that there is much more evidence of a stable panel cointegrating relationship between lending rates and funding costs based on the WACL(stock) and WACL (flow) measures than for lending rates and policy rates. This implies a stronger and more reliable relationship between lending rates and WACL compared to the results for policy rates.

\subsection{Structural Breaks}

Before we consider the magnitude of pass-through for bank funding costs, we repeat the cointegration tests by allowing for structural breaks in our data after the financial crisis. Graph 1 indicates that there was a well-defined level shift in the policy rate in the euro area, Denmark and the United Kingdom. Failure to allow for structural breaks can have harmful effects on the size and power of cointegration tests according to evidence in Banerjee and Carrion-i-Silvestre (2013). Therefore, we utilize their procedure to search for a cointegrating relationship allowing for a structural break and cross-sectional dependence in the panel.

Banerjee and Carrion-i-Silvestre (2013) allow for several potential breaks in intercept, trend and the cointegrating relationship, which can be transferred to our model defined by equation (6), plus some assumptions about the driving processes for $e_{i t}$ and $x_{i t}$. The methodology allows for multiple breaks, and the number and position of the breaks need not coincide for each country in the panel. We can consider a break process defined by

$$
D_{i t}=\mu_{i}+\phi_{i} t+\sum_{j=1}^{m_{i}} \theta_{i j} D U_{i j t}+\sum_{j=1}^{m_{i}} \gamma_{i j} D T_{i j t}
$$

where the $i=1, \ldots, N$ and $t=1, \ldots, T$. The effect of the break is modelled using $D U_{\mathrm{ijt}}=1$ and $D T_{i j t}=(t-$ $T^{b_{i j}}$ ) for $t>T^{b_{i j}}$ and 0 otherwise, where $T^{b_{i j}}=\lambda b_{i j} T$ for $\lambda b_{i j} \in(0,1)$ reflects the location of the break in trend, and $\theta_{i t}=\theta_{i j}$ for $T c_{i j-1}<t<=T c_{i j}$, where $\lambda c_{i j} \in(0,1)$ is the location of the break in the cointegrating relationship. Therefore the model can investigate the possibility of a break in the intercept $\left(D U_{i j t}\right)$, a change in trend $\left(D T_{i j t}\right)$, or a break in the cointegrating vector $\left(\theta_{i t}\right)$, which is a function of time in their model.

We report the results in Table 2 for a model allowing for a break in the intercept $\left(Z_{a}\right)$ and a model allowing a break in the intercept and the cointegrating vector $\left(Z_{a c}\right)$, for our four lending rates versus policy rates and then versus our WACL measure. The test statistics reject the null of no cointegration at conventional levels of significance against the alternative of cointegration for all four lending rates with our WACL measure, indicating evidence that the cointegrating relationships is robust to the inclusion of a structural break in the intercept, but less so for the cointegrating vector, for which only one rejection is found. The results for policy rates are much weaker and point to rejection of the null only in one case. These tests lead us to conclude that our 
results are not completely overthrown when we allow for cross sectional dependence and a structural break in the equation.

\section{Modelling Rates in a Dynamic Heterogeneous Panel}

We wish to explore the relationship between the lending rates and the funding costs in a dynamic heterogeneous panel pooled mean group (PMG) estimator first proposed by Pesaran and Smith (1995) and Pesaran, Shin and Smith (1999) in order to obtain an estimate of the degree of passthrough. This introduces a (common) long-run relationship corresponding to the cointegrating relationship we obtained in the previous section. Once again we take $y_{i t}$, as the lending rate and $x_{i t}$, as the driver of the lending rate (i.e. the policy rate or the WACL) in an ARDL model with lags $P, Q$ (determined by the Bayesian Information Criterion, BIC), as follows:

$y_{i t}=\sum_{p=1}^{P} \chi_{i p} y_{i t-p}+\sum_{q=0}^{Q} \delta_{i q} x_{i t-q}+\mu_{i}+e_{i t}$

This can be rewritten as a stacked set of $N$ individual equations relating $y_{i t}$ and $x_{i t}$ for groups $i=$ $1,2, \ldots N$ over the time period $t=1,2, \ldots T$ as

$\Delta Y_{i}=\alpha_{i} Y_{i,-1}+\beta_{i} X_{i}+\sum_{p=1}^{P-1} \chi_{i p} \Delta Y_{i,-p}+\sum_{q=0}^{Q-1} \delta_{i q} \Delta X_{i,-q}+\mu_{i} 1+\varepsilon_{i}$

where $Y_{i}=\left(y_{i 1}, \ldots y_{i T}\right)^{\prime}, X_{i}=\left(x_{i 1}, \ldots x_{i T}\right)^{\prime}, 1=(1, \ldots, 1)^{\prime}, \varepsilon_{i}=\left(e_{i 1}, \ldots e_{i T}\right)^{\prime}$ are all $T \times 1$ vectors of observations, ones and residual errors, and $\Delta$ is the first difference operator.

The model can be re-specified as:

$$
\Delta Y_{i}=\alpha_{i}\left(Y_{i,-1}-\theta_{i} X_{i}\right)+\sum_{p=1}^{P-1} \chi_{i p} \Delta Y_{i,-p}+\sum_{q=0}^{Q-1} \delta_{i q} \Delta X_{i,-q}+\mu_{i} 1+\varepsilon_{i}
$$

where the relationship $\alpha_{i}\left(Y_{i,-1}-\theta_{i} X_{i}\right)$ for the levels provides information on the long-run cointegrating relation between lending rates and driving variables that we discovered in the previous section. Long-run homogeneity is imposed by setting $\theta_{i}=\theta \cdot{ }^{17}$ Estimates of $\beta_{i}=\alpha_{i} \theta_{i}$ allow us to derive the long-run pass-through coefficients by dividing through by $\alpha_{i}$, the adjustment speed of rates to deviations from this long-run relationship for each country $i$.

To mitigate the effects of cross-sectional dependence we introduce cross-sectional averages of the differences and lagged differences in each variable following Pesaran (2006), Chudik and Pesaran (2015) and Eberhardt and Presbitero (2016) as follows:

\footnotetext{
${ }^{17}$ The PMG model imposes long-run homogeneity while a mean group estimator (MGE), which is a plain average of individual group i estimates of equations stacked in (12), does not. The MGE estimator is consistent but inefficient if there is a common slope coefficient.
} 


$$
\begin{aligned}
& \Delta Y_{i}=\alpha_{i}\left(Y_{i,-1}-\theta_{i} X_{i}\right)+ \\
& \sum_{r=2}^{R} \pi_{i r} \Delta \bar{Y}_{i,-r}+\sum_{s=2}^{S} \pi_{i s} \Delta \bar{X}_{i,-s}+ \\
& \sum_{p=1}^{P-1} \chi_{i p} \Delta Y_{i,-p}+\sum_{q=0}^{Q-1} \delta_{i q} \Delta X_{i,-q}+\mu_{i} 1+\varepsilon_{i}
\end{aligned}
$$

Terms that are over-scored are the cross-sectional averages of each variable: $\Delta \bar{Y}_{i}=N^{-1} \sum_{i=1}^{N} \Delta Y_{i}$ and $\Delta \bar{X}_{i}=N^{-1} \sum_{i=1}^{N} \Delta X_{i}$. Lag lengths $R, S=\operatorname{int}\left(T^{1 / 3}\right)$. Equation (11) therefore represents a dynamic PMG estimator, similar to that used by Binder and Offerman (2012), whereby crosssection averages are added to the PMG. The model can be estimated by OLS, since the terms in first differences of cross-sectional averages and first differences allow for non-stationarity, crosssectional correlation, heterogeneity and non-linearity or asymmetry in the data (see Eberhardt and Presbitero, 2016).

\subsection{Estimates of Pass-through from Funding Costs and Policy Rates}

In the context of the PMG model (11) it is possible to estimate a model allowing for a common long-run pass-through relationship with heterogeneous responses in the short run to reflect institutional differences across countries. We report our baseline results in Table 3 for WACL(stocks) and WACL(flows). We split the sample of countries into three groups: the first group includes all 11 countries in the euro area as well as the UK and Denmark, the second refers only to the euro area and the third includes only core euro area countries (i.e. excluding Ireland, Italy, Portugal and Spain). The tables report common long-run coefficient estimates of the relationship between the four different interest rates (short-term and long-term loans to business and short-term and long-term mortgages, in successive columns) versus funding costs, over the full sample period January 2003 - December 2017. We also report the estimate of the average adjustment to the long-run relationship for each group of countries.

Results for WACL(stocks) are displayed in the first panel. We find that the common passthrough coefficient estimates take plausible positive values, which are significantly less than one for the full sample. This implies that a 100bp increase the WACL(stocks, adjusted) funding cost for banks would result in an increase in lending rates between 87-98bp. Long-term and shortterm lending rates show degrees of interest rate pass-through consistent with the findings in the previous literature (see De Bondt et al., 2005, Hristov et al., 2014). Restricting the sample of countries to the euro area countries or the euro area core does not substantially change the estimates. A similar pattern is observed in the second panel where we report the results for WACL(flows, unadjusted) since estimated pass-through coefficients are between 85-96bp. The comparability of the estimated pass-through coefficients makes an important point that our 
results are robust to the choice of funding weights, since the similarity of the results using either stocks- or flows-based weights in the construction of the funding costs does not materially alter the majority of pass-through estimates. ${ }^{18}$

In Table 3, we also report the average of short-run adjustment coefficients for each group of countries in two rows. To ensure that our results that average across countries are not unduly influenced by outlying observations, we can estimate the MGE model robustly. ${ }^{19}$ The first row shows the estimates with equal weights on the observations of each country, while the second adjusts the weight according to the proximity of the country observation to the average value for all countries, which we refer to as the robust estimate. The adjustment coefficients are negative and significant in every case for each of the panels. The adjustment speed is generally faster for short- and long-term lending rates to business than to households: the estimated coefficients are two or three times larger for lending rates to business using WACL(stocks) or WACL(flows) compared to the adjustment coefficients for households. The difference in the adjustment speed is illustrated by the half-life calculations reported for each of the lending rates, which show decay is faster for lending rates to business (around 6 months) compared with lending rates for households (around 10 months). This may be a consequence of the bespoke nature of loans to business, which are likely to adjust to prevailing conditions more quickly than loans to households, which are generic products. The t-bar test for the PMG model shows that the adjustment coefficient is significantly different from zero when averaged across countries.

These findings contrast markedly with results for policy rates reported in Table 4, where pass-through estimates tend show more variation over the full sample according to the type of lending rate under consideration, compared to WACL results in Table 3. Short-term rates to NFCs appear to have similar degree of pass-through as do short rates to households for the euro area and euro core countries, but short rates for mortgages over the full sample of countries has a much lower pass-through coefficient and long-term rates are noticeably lower across the board. However, results for a shorter sample up to the beginning of the global financial crisis, indicate pass-through estimates that are closer to the estimates provided by the WACL in Table 3. It is

\footnotetext{
${ }^{18}$ One reason for this result may be that funding weights adjust relatively slowly compared to funding rates, therefore variation in WACL(stocks) versus WACL (flows) may be mostly determined by changes in rates not weights.

${ }^{19}$ We compute the common relationship in lag levels using PMG and then estimate the MGE estimate using the calculated error correction term and robustness. Robustness ensures that the weight on each country is based on the proximity of the country observation to the average of all countries, reducing the influence of outlier observations compared to the non-robust estimates which use a $1 / \mathrm{N}$ weighting scheme for observations from each country. We report results from PGE and MGE(robust) methods. We follow standard practice in the literature by using robust regression (see Hamilton, 1992) to reduce the weight on outliers in the computation of the averages.
} 
only when using the full sample that we also find adjustment speeds are different when estimated using policy rates or WACL, and the half-life for most of the lending rates is longer than the halflife reported in Table 3 for samples including all eleven countries or the euro area, implying a discernible change in response to policy rates after the crisis.

\subsection{Relationships with Components of the WACL}

In the previous section we have shown that there is a strong and stable relationship between the various lending rates and the weighted average cost of liabilities. By examining the relationship between the components of the WACL and lending rates using the same techniques documented above we can examine whether components have the same relative importance and if we find they do not, we can take a stance on which type of funding cost is most important.

The results of our analysis are reported in Tables 5 and 6. -Table 5 shows the evidence for a cointegrating relationship between short-term and long-term lending rates of different types and each of the components: MFI deposits, non-MFI deposits and short-term securities. -Short-term lending rates to non-financial companies are most closely related to short-term securities (according to Persyn-Westerlund and Banerjee-Carrion-i-Sylvestre tests), and also related to deposits of MFIs or non-MFIs (according to the Banerjee-Carrion-i-Sylvestre tests alone). Shortterm mortgages are more closely linked to deposits (according to Persyn-Westerlund and Banerjee-Carrion-i-Sylvestre tests), and related to securities (according to the Banerjee-Carrioni-Sylvestre test). Long-term lending to companies is cointegrated with all types of funding but there is more consistent support for a relationship with long-term securities of different types. Long-term lending rates on mortgages are statistically connected to many different types of funding but most closely to deposits.

We noted previously that these funding costs were elevated compared to policy rates, and the effects are transmitted to lending rates. It is possible to interpret the cointegrating relationships between separate components as evidence that explains the reason for the higher funding costs. For example, the consistent evidence that short-term securities yields are cointegrated with lending rates offered to NFCs implies higher securities yields (possibly due to higher yields on sovereign bonds of similar maturity) were an important driver of the WACL in this case. Shortterm mortgages seem to be more consistently cointegrated with MFI and non-MFI deposits therefore we may conclude the elevated WACL measure in this case reflects the higher cost of unsecured interbank deposits (counterparty risk) and the higher competition for deposits from non-financial that raised their cost. Longer-term lending to non-financial companies and 
mortgages are influenced by all types of funding but with more influence from securities for lending rates to non-financial companies and deposits for mortgages. This indicates the that rising weighted average costs are more broadly based on all types of funding but are primarily driven by similar risk factors and competitive pressures that influenced short rates.

Examining the components of the WACL adds further insights and makes clearer how monetary policy is transmitted through the WACL to lending rates. There is a rationale for conventional monetary policies to target short rates and unconventional policies to target long term rates. In terms of financial stability, the maturity alignment eases concerns about maturity mismatches on bank balance sheets. Taken at face value, therefore, our results would suggest that in order to stimulate long-term lending, the central bank should aim at keeping a lidto influence-on the components of the long-term WACL, which is best achieved using unconventional policy measures. While this is somewhat at odds with the common view that commercial banks engage in, and profit mostly from, activities related to maturity transformation, we also have to remark that such activities may be too risky in a highly uncertain environment and with unconventional policy measures flattening the yield curve.

In Table 6 we explore the estimates of the adjustment coefficient (adjusted and unadjusted). The coefficients are negative and significant in every case for each of the panels, but the magnitudes of the coefficients differ by quite a large margin. The adjustment speed is generally slower for those components that showed the strongest evidence of cointegration in Table 5 and the corresponding half-life calculations show decay is slower for these components.

\subsection{Other Robustness Checks}

The previous tables have presented the long-run relationships and the average adjustment coefficients across countries when we estimate the pass-through relationship over the full Jan2003-Dec2017 sample. We now consider sub-samples of the data to explore the pass-through of WACL to lending rates up to three successive break points in the data. The first break point is the onset of the global financial crisis (GFC), July 2007, after which bank funding costs increased significantly. The second is the point just before Lehman collapsed and the recession took hold, August 2008, where the data show that there was a deterioration in economic growth rates leading to a recession. ${ }^{20}$ The third break point is just prior to the sovereign debt crisis, December 2009: banks in vulnerable countries were shut out of the bond market (or faced exceptionally

\footnotetext{
${ }^{20}$ The growing intensity of the recession is also reflected in the fact that, banks began to tighten credit conditions in 2008Q3 according to the ECB Bank Lending Survey, and house prices began to fall.
} 
very high costs), and perceptions of default risk for banks increased (as shown by the increased correlation of bank CDS spreads with sovereign CDS spreads).

Table 7 reports the pass-through coefficients for WACL(stocks) data for these three break points for the euro area countries. The interesting result is that coefficient estimates are larger in magnitude compared with those reported in Table 4 (a result also observed by Von Borstel et al. 2015 in the context of their FAVAR model). When we end the sample in July 2007, the passthrough is close to one for all four lending rates. Pass-through was essentially complete before the crisis, and higher than the estimate for the full sample reported in Table 4. Adjustment speeds were also about $50 \%$ higher, and for lending to business the adjustment coefficients were $100 \%$ larger, than those reported in Table 3. This resulted in lower half-life values for all lending rates over the pre-crisis sample. When we break the data in August 2008 the estimated coefficients are smaller in three cases out of four compared to the sample up to July 2007, but larger than the full sample estimates from Table 3. Adjustment speeds fall a little or stay the same compared to estimates to July 2007, and half-life values rise in two cases. If we break the data in January 2010 at the start of the sovereign debt crisis, we find the estimated pass-through drops a little further, especially for long rates, and adjustment speeds are about the same. This evidence seems to suggest that pass-through was higher in the pre-crisis period, and has fallen to some degree through the post-crisis period culminating in slightly lower but substantial values for passthrough for the full sample reported in Table 4.

The conclusion we draw from these tables is that the coefficient estimates from a carefully constructed weighted average cost of liabilities over a range of sample endpoints still gives results that imply substantial pass-through of funding costs to lending rates. It is hard to argue from these results that banks response to funding costs has fundamentally changed in the post crisis period, although there is some evidence that adjustment speeds associated with passthrough have declined more substantially.

\section{The dynamic transmission of monetary policy and bank funding shocks}

Under the traditional analytical framework according to which lending rates were tied to policy rates, central banks could easily steer the former by moving the latter. Our evidence of a breakdown in the above-mentioned relationship, however, calls into question the ability itself of central banks to control lending rates, at least through conventional monetary policy. But since the onset of the Great Financial Crisis, major central banks have deployed a large spectrum of unconventional policies with the objective to stimulate lending. In this section, we briefly explore the extent to which such unconventional monetary policy actions have dynamically influenced bank funding costs and hence lending rates. We will do so in two steps. 
First, we assess the extent to which exogenous unconventional monetary policy shocks have been able to influence bank funding costs over time. To do so, we find convenient to bypass the problem of finding an appropriate identification scheme, and resort to off-the-shelf shocks. We based our analysis on the "target" and "path" shocks identified by Ferrari et al (2017) in a high-frequency event study of the ECB actions. In very simplified terms, the first shock corresponds to moves in the intercept of the yield curve, while the second one relates to its slope. One can then interpret the first as a change in the desired level of interest rates (which makes it akin to a change in policy rates in the pre-ZLB times), and the second as a change in the path of adjustment to that level, which also includes the term premium (i.e. something closer to forward guidance). We then aggregate such shocks at our monthly frequency and conduct a local projection exercise (Jorda 2005) in which bank funding costs are regressed on different lags of the shocks, as well as other control variables (GDP growth, inflation, policy rates).

Responses for the short- and long-term WACL are displayed in Graph 5. As discussed above, the "target" shock resembles more closely a conventional shock to policy rates, and therefore it is not surprising to observe that it seems to transmit significantly to the WACL (especially the short-term one). The results for the "path" shocks are instead more mixed: shortterm WACL responds only with a substantial lag, arguably when the rates start following the indicated "path", while the long-term WACL does not respond significantly. What we learn from these results is that overall ECB unconventional policies successfully managed to steer bank funding costs - especially the short-term ones. Our results also seem to suggest that the commitment to maintain accommodative conditions transmitted more strongly compared to the attempts to keep long-term rates low.

As a second step, we check how bank funding costs transmit to lending rates once such unconventional monetary policy shocks are accounted for. To do so, we resort to a panel VAR (see Canova and Ciccarelli, 2013 for an overview of panel VAR methods and applications). More specifically, we employ the methodology proposed by Love and Zicchino (2006) and further developed in Abrigo and Love (2015), which is based on pooled estimation. To identify the shock to funding cost correctly, i.e. a change, which is orthogonal to other endogenous factors that may drive its dynamics, we resort to Choleski decompositions, which are a well-established tool in the VAR literature. ${ }^{21}$ Our starting point are the monetary VARs popularised by Bernanke and Blinder (1992), where an exogenous shock to monetary policy is identified by controlling for movements in GDP and inflation, which could affect the endogenous response of policy rates. This is

\footnotetext{
${ }^{21}$ Love and Zicchino (2006) also rely on a Choleski decomposition to identify the shocks.
} 
sometimes referred to as a slow-to-fast identification strategy. We adopt a similar reasoning for bank funding costs, and add lending rates to the VAR, to investigate their dynamic reaction. Therefore, our VAR includes (in this order) real GDP growth, CPI inflation, bank funding costs and the lending rates, with all variables in levels.

Based on the ordering laid out above, the underlying identifying assumption for the shock to bank funding costs is that they are allowed to react contemporaneously to all the other variables in the system except the lending rate, which is instead unrestricted. Moreover, the resulting shock to bank funding costs is net of changes due to the business cycle, as controlled for by GDP and inflation. Moreover, to account for the extent of (conventional and unconventional) monetary stimulus deployed by the ECB during the period under review, we also include as exogenous variables a series of monetary policy shocks, as identified by Ferrari et al (2017). By doing so, we also net the bank funding costs shock from such (exogenous) monetary shocks.

The results are reported in Graph 6. The (cumulated) impulse response is given by a thin solid line in each graph, with standard errors represented by the shading. In all four panels, we see the expected positive response in lending rates to a positive shock to funding costs that dies away gradually over time. These results are consistent with the cointegration analysis and further strengthen our baseline results: the transmission of bank funding shocks to short-term lending rates is stronger; the transmission to rates to non-financial corporations also appears a bit stronger compared to that on mortgages and, importantly, the dynamic relationship survives controlling for exogenous monetary policy shocks.

At first sight, the use of an unrestricted VAR specification may seem at odds with the cointegrating framework adopted in the previous sections. However, we remark that unrestricted VARs allow cointegrating relationship to emerge from the data, in case they are strongly supported by the correlation pattern. In this case, the endpoint of the cumulated IRFs is similar to the estimated long-term pass-through of a one standard deviation shock to bank funding costs to the corresponding lending rate, although we are more interested in the dynamic path after a one standard deviation shock to bank funding costs than the implied long-run pass through.

\section{Conclusions}

Many observers have noted since the global financial crisis that lending rates set by banks have not fallen as much as policy rates (see ECB, 2012; Beirne, 2012; ECB, 2013; Hristov et al., 2014; Von Borstel et al, 2015) and funding costs have become more dispersed across Europe (see Albertazzi et al 2012; Arnold and van Ewijk, 2014; Darracq-Paries et al. 2014; De Sola Perea and 
Van Nieuwenhuyze, 2014; Holton and Rodriguez, 2015). This poses important questions for monetary policymakers who are seeking to determine whether banks are taking advantage of the low interest rate environment by failing to pass on lower rates to loans, or whether a break in the relationship between policy rates and lending rates has altered the way central banks should model the transmission mechanism. These are core issues in the debate about the effectiveness of monetary policy and the price of bank lending in Europe; as such, they have attracted plenty of attention from central banks (see ECB 2015, 2016).

We investigate the relationship between lending rates, bank funding and policy rates over the period 2003 - 2017 for 11 European countries inside and outside the euro area using dynamic panel methods that allow for heterogeneity and cross country dependence developed by Pesaran (2006) and Chudik and Pesaran (2015). This extends previous panel VAR models of interest rate pass-through that have not considered these features. Our results show that there is stronger evidence for a stable relationship between lending rate and a weighted average cost of liabilities (WACL) measure than for policy rates. There are powerful arguments in support of a funding measure based on a broad range of banks' liabilities that are strengthened further by these results. We conclude that funding costs broadly defined are most relevant to lending rates since there is no divergence in the post crisis period. Policy rates on the other hand, which were a reasonable proxy for funding costs before 2007 when liquidity and counterparty risks were low and stable, are no longer good proxies under conditions that have substantially changed. Our findings have refocused attention on the cost and composition of bank funding as a means to understand interest rate pass-through, which has been acknowledged by central banks (ECB, 2015; ECB, 2016) and through real interest rates explain cyclical differences in monetary transmission through the investment channel (European Commission, 2016).

\section{References}

Abrigo, Michael R.M. and Inessa Love (2015): "Estimation of Panel Vector Autoregression in Stata: A package of programs", University of Hawaii working paper.

Adrian, Tobias, Paolo Colla and Hyun S. Shin (2013) "Which Financial Frictions? Parsing the Evidence from the Financial Crisis of 2007-9” 2012 NBER Macroeconomics Annual, Volume 27, Daron Acemoglu, Jonathan Parker, and Michael Woodford, (Eds), 159 - 214, 2013.

Albertazzi, Ugo, Tiziano Ropele, Gabriele Sene and Federico M. Signoretti (2014): "The Impact of the Sovereign Debt Crisis on the Activity of Italian Banks," Journal of Banking and Finance, 46, 387-402.

Arestei, David and Manuella Gallo, (2014) "Interest Rate Pass-Through in the Euro Area During the Financial Crisis: A Multivariate Regime Switching Approach", Journal of Policy Modelling, 36, 273-95.

Arnold, I., and S. Van Ewijk (2014): "The impact of sovereign and credit risk on interest rate convergence in the euro area," DNB Working Papers 425, Netherlands Central Bank, Research Department.

Banerjee, Anindya, Victor Bystrov and Paul D. Mizen (2013): "How Do Anticipated Changes to Short-Term Market Rates Influence Banks' Retail Interest Rates? Evidence from the Four Major Euro Area Economies”, Journal of Money, Credit and Banking, 45, 1375-414. 
Banerjee, Anindya and Josep Carrion-I-Silvestre (2004): "Breaking panel data cointegration", http://www.cass.city.ac.uk/_data/assets/pdf_file/0003/64911/Banerjee-and-Carrion-i-Silvestre-2004.pdf

Banerjee, Anindya and Josep Carrion-I-Silvestre (2013): “Cointegration in Panel Data with Structural Breaks and Cross Sectional Dependence”, Journal of Applied Econometrics, doi: 10.1002/jae.2348.

Beirne, John (2012): “The EONIA Spread Before and After the Crisis of 2007-2009”, Journal of International Money and Finance, 31, 534-51.

Beirne, John, Marcel Fratzscher (2013) “The Pricing of Sovereign Risk and Contagion During the European Sovereign Debt Crisis", Journal of International Money and Finance, 34, 60-82.

Belke, Ansgar, Joscha Beckmann, Florian Verheyen (2013): "Interest Rate Pass-through in the EMU - New Evidence from Nonlinear Cointegration Techniques for Fully Harmonized Data” Journal of International Money and Finance, 37, 1-24.

Berlin, Mitchell and Lorretta J. Mester (1999): “Deposits and Relationship Lending”, Review of Financial Studies, 12 (3), 579-607.

Bernanke, Ben and Alan Blinder (1992): "The federal funds rate and the channels of monetary transmission”, American Economic Review, 82, 901-921.

Binder, Michael and Offerman (2012) "Dynamic Panel Data Models with Heterogeneous Slope - Conditional Pooled Mean Group Estimation and Empirical Illustration“ http://www.wiwi.uni-Frankfurt.de/profs/binder/teaching/ ccsm1112/restrict/ccs1112-4p3.pdf

Borio, Claudio E.V., and Wilhelm Fritz. (1995) "The Response of Short-Term Bank Lending Rates to Policy Rates: a Cross Country Perspective." BIS Working Paper No. 27.

Brainard, William (1967) "Uncertainty and the Effectiveness of Policy”, American Economic Review Papers and Proceedings, 57, 211-225.

Canova, Fabio, and Matteo Ciccarelli, (2009) “Estimating Multi-country VAR models” International Economic Review, 50, 929-961.

Canova, Fabio and Matteo Ciccarelli, (2013) "Panel Vector Autoregressive Models: A Survey”, ECB Working Paper No 1507, January 2013

Caruana, Jaime and Adrian van Rixtel (2013) “International Financial Markets and Bank Funding in the Euro Area: Dynamics and Participants", www.bis.org/publ/other18.pdf.

Chudik, Alexander and M. Hashem Pesaran, (2014) "Aggregation in Large Dynamic Panels,", Journal of Econometrics, 178, 273-285.

Churm, Rohan and Amar, Radia (2012) “The Funding for Lending Scheme” Bank of England Quarterly Bulletin, Vol. 52, pages 306-20.

Darraqc-Paries Matthieu, Diego N. Moccero, Elizaveta Krylova and Claudia Marchini (2014) “The Retail Bank Interest Rate Pass-Through: The Case of the Euro Area During the Financial and Sovereign Debt Crisis", ECB Occasional Paper Series 155, September.

De Bondt, Gabe (2002) "Retail Bank Pass-through: New Evidence at the Euro Area Level." ECB Working Paper No. 136.

De Bondt, Gabe (2005) “Interest Rate Pass-Through: Empirical Results for the Euro Area”, German Economic Review 6, 37-78.

De Bondt, Gabe, Benoit Mojon, Natacha Valla (2005) "Term Structure and the Sluggishness of Retail Bank Interest Rates in Euro Area Countries”, ECB Working Paper No. 518.

De Graeve, F., O. De Jonghe and R.V. Vennet (2007), “Competition, Transmission and Bank Pricing Policies: Evidence From Belgian Loan and Deposit Markets”, Journal of Banking and Finance, 31, 259-78.

De Sola Perea M. and Ch. Van Nieuwenhuyze (2014), "Financial integration and fragmentation in the euro area", National Bank of Belgium Economic Review, 99-125.

ECB (2009) "Recent Development in the Retail Bank Interest Rate Pass-Through in the Euro Area”, ECB Monthly Bulletin, 93-105..

ECB (2010a) “The ECB's Response to the Financial Crisis”, Monthly Bulletin, October, 59-74.

ECB (2010b) Euro Money Market Study, December.

ECB (2012) "Heterogeneity in Euro Area Financial Conditions and Policy Implications”, Monthly Bulletin, August $2012,63-75$.

ECB (2013) "Assessing the Retail bank Interest Rate Pass-Through in the Euro Area at Times of Financial Fragmentation”, Monthly Bulletin, August 2013, 75-91. 
ECB (2015) “The Transmission of the ECB’s Recent Non-Standard Monetary Policy Measures” Economic Bulletin, Issue 7 / 2015.

ECB (2016) "Recent Developments in the Composition and Cost of Bank Funding”, Economic Bulletin Issue 2/2016

Eberhardt, Markus and Andrea F. Presbitero (2016) "Public Debt and Growth: Heterogeneity and Non-Linearity" Journal of International Economics, 97, 45-58.

Ehrmann, Michael., Leonardo Gambacorta, J. Martinez-Pages, Patrick Sevestre and Andreas Worms (2003),"Financial Systems and the Role of Banks on Monetary Policy Transmission in the Euro Area", in: Monetary Policy Transmission in the Euro Area , Cambridge University Press, 235-69.

Elyasiani, Elyas, Kopecky, Kenneth J., and David Van Hoose. (1995) "Costs of Adjustment, Portfolio Selection, and the Dynamic Behavior of Bank Loans and Deposits." Journal of Money, Credit, and Banking, 27, 955-974.

Ferrari, Massimo, Jonathan Kearns and Andreas Schrimpf (2017), "Monetary policy's rising FX impact in the era of ultra-low rates", BIS Working Papers 626.

Fungáčová, Zuzana, Laura Solanko and Laurent Weill (2014), "Does competition influence the bank lending channel in the euro area?", Journal of Banking and, Finance, 49, 356-366.

Gambacorta, Leonardo. (2008) "How Do Banks Set Interest Rates?" European Economic Review, 52, 792-819.

Gambacorta, Leonardo and Paul Mizen. (2019). "Inside the Bank Box: Evidence on Interest-Rate Pass- Through and Monetary Policy Transmission”, in Handbook on the Economics of Central Banking, \{P Siklos and D Mayes Eds) Oxford University Press.

Gertler, Mark, and Peter Karadi. 2015. "Monetary Policy Surprises, Credit Costs, and Economic Activity." American Economic Journal: Macroeconomics, 7(1): 44-76.

Gerali, Andrea, Stefano Neri, Luca Sessa, and Federico Signoretti (2010) “Credit and Banking in a DSGE Model of the Euro Area", Journal of Money, Credit and Banking, 42, 107-141.

Gilchrist, Simon and Benoit Mojon (2014) "Credit Risk in the Euro Area”, NBER working paper.

Goggin, Jean, Sarah Holton, Jane Kelly, Reamonn Lydon and Kieran McQuinn (2012) "The financial crisis and the pricing of interest rates in the Irish mortgage market: 2003-2011" Central Bank of Ireland working paper $01 R T 12$.

Goodfriend, Marvin (1991) “Interest Rate Smoothing and the Conduct of Monetary Policy”, Carnegie-Rochester Conference of Public Policy, 7-30

Gregory, Allan M. and Bruce E. Hansen (1996) "Residual-based Tests for Cointegration in Models with Regime Shifts", Journal of Econometrics, 70, 96-126.

Hamilton, Lawrence C. (1992) “How Robust is Robust Regression?”, Stata Technical Bulletin, 1(2).

Hannan, Timothy H. and Allen N. Berger (1991) "The Rigidity of Prices: Evidence from the Banking Industry," American Economic Review , 81, 938-45.

Hofmann, Boris and Paul D. Mizen. (2004) "Interest Rate Pass-through in the Monetary Transmission Mechanism: Evidence from Individual Financial Institutions' Retail Rates." Economica, 71, 99-125.

Holton, Sarah and Costanza Rodriguez d'Acri (2015) "Jagged Cliffs and Stumbling Blocks: Interest Rate Passthrough Fragmentation during the Euro Area Crisis”, Central Bank of Ireland working paper 01RT15.

Hristov, N. O. Hulsewig, and T Wollmershauser (2014) "The Interest Rate Pass-through in the Euro Area During the Global Financial Crisis", Journal of Banking and Finance, 48, 104-119.

Illes, Anamaria and Marco Lombardi (2013) “Interest Rate Pass-through Since the Financial Crisis”, BIS Quarterly Review, September 2013.

Im, Kyung So, Pesaran M. Hashem, and Youngcheol Shin (2003) "Testing for Unit Roots in Heterogeneous Panels", Journal of Econometrics 115, 53-74.

Jordà, Oscar (2005): “Estimation and Inference of Impulse Responses by Local Projections”, American Economic Review, 95, 161-82.

Klemperer, Paul (1987) “Markets with Consumer Switching Costs,” Quarterly Journal of Economics , 102, 375-394.

Kok-Sørensen, Christoffer, and Thomas Werner. (2006) "Bank Interest Rate Pass-through in the Euro Area." ECB Working Paper No 580.

Kopecky, Kenneth J., and David Van Hoose. (2012) "Imperfect Competition in Bank Retail Markets, Deposit and Loan Rate Dynamics, and Incomplete Pass-through." Journal of Money, Credit, and Banking,

Kose, A. Otrok, C. and Whiteman, C., (2003) "International Business Cycles: World, Region, and Country-Specific Factors". American Economic Review, 93, 1216-1239.

Formatted: Font: Italic

Formatted: Font: Italic

Formatted: Indent: Left: $0 \mathrm{~cm}$, First line: $0 \mathrm{~cm}$ 
Kwapil, Claudia. and Johann Scharler (2010), 'Interest Rate Pass-Through, Monetary Policy Rules and Macroeconomic Stability', Journal of International Money and Finance, 29, 236-51.

Love, Inessa and Lea Zicchino (2006: "Financial development and dynamic investment behavior: Evidence from panel VAR", The Quarterly Review of Economics and Finance, 46, 190-210.

Masimo, Ferrari, Jonathan Kearns and Andreas Schrimpf (2017) “Monetary policy's rising FX impact in the era of ultra-low rates" BIS Working Paper 626.

Mojon, Benoit. (2000) "Financial Structure and the Interest Rate Channel of ECB Monetary Policy." ECB Working Paper No 40.

Orphanides, Athanasios (2003) "Monetary Policy Evaluation with Noisy Information," Journal of Monetary Economics, 50, 605-631.

Neumark, David, and Steven A. Sharpe (1992) "Market Structure and the Nature of Price Rigidity: Evidence from the Market for Consumer Deposits, Quarterly Journal of Economics, 107, 657-80.

Persyn, Damiaan and Joakim Westerlund (2008) "Error-Correction-Based Cointegration Tests For Panel Data" The Stata Journal, 8: 232-241.

Pesaran, M.Hashem and Ron Smith (1995) “Estimating Long-Run Relationships From Dynamic Heterogeneous Panels", Journal of Econometrics 68: 79-113.

Pesaran, M. Hashem., Youngcheol Shin, and Ron Smith (1999) "Pooled Mean Group Estimation of Dynamic Heterogeneous Panels", Journal of the American Statistical Association 94: 621-634.

Pesaran, M. Hashem. (2006) “Estimation and Inference in Large Heterogenous Panels with Multifactor Error Structure”. Econometrica 74, 967-1012.

Pesaran, M.Hashem. (2007) “A simple panel unit root test in the presence of cross-section dependence”, Journal of Applied Econometrics, 22: 265-312.

Rogers, John, C. Scotti and Jonathan H. Wright (2014) "Evaluating Asset-Market Effects of Unconventional Monetary Policy: A Cross Country Comparison", Economic Policy, 29, 749-799.

Sack, Brian (2000), "Does the Fed Act Gradually? A VAR Analysis”, Journal of Monetary Economics, , 46, 229-256

Sorensen, C and T. Werner, (2006) ank Interest Rtae Pass-Through in the Euro Area: A Cross Country Comparison", ECB working paper No. 580.

Stahl, D.O. (1988) "Bertrand competition for inputs and Walrasian outcomes", American Economic Review 78, 189201.

Turner, Philip (2013) “Benign Neglect of the Long Term Interest Rate”, BIS working paper 403

Van Rixtel, Adrian and Gabrielle Gasperini (2013) "Financial crises and bank funding: Recent experience in the euro area" BIS Working Paper 406.

Von Borstel, Julia, Eickmeier, Sandra, and Leo Krippner (2016), “The Interest Rate Pass-through in the Euro Area During the Sovereign Debt Crisis", Journal of International Money and Finance, 68, 386-402.

Westerlund, Joakim (2007) "Testing for Error Correction in a Panel Data", Oxford Bulletin of Economics and Statistics, 69, 709-748.

Yanelle, Marie-Odile (1997) “Banking Competition and Market Efficiency”, Review of Economic Studies 64, 215-39.

Zoli, Edda (2013) "Italian Sovereign Spreads: Their Determinants and Pass-Through to Bank Funding Costs and Lending Conditions”, IMF Working Paper No. 13/84. 
MFI lending rates for selected countries: short- and long-term

In per cent

Graph 1

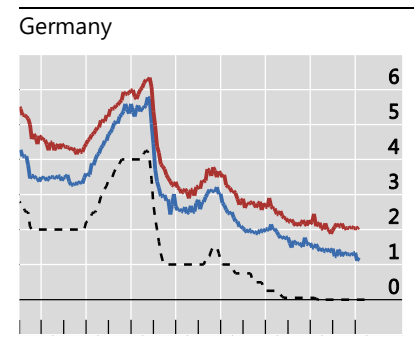

$\begin{array}{llllllll}04 & 06 & 08 & 10 & 12 & 14 & 16 & 18\end{array}$ Short-term lending rates ${ }^{1}$ : - Residential

Spain

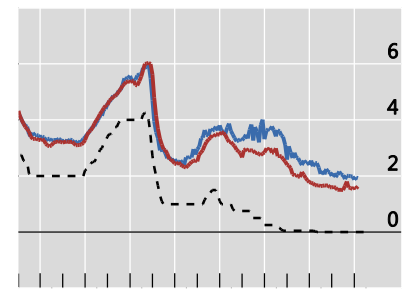

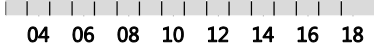

Germany

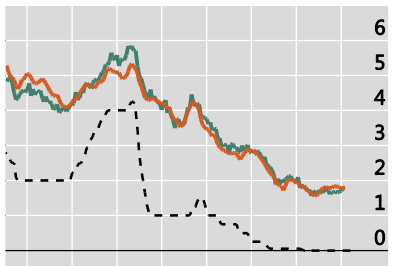

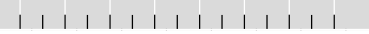

$\begin{array}{llllllll}04 & 06 & 08 & 10 & 12 & 14 & 16 & 18\end{array}$ Long-term lending rates $^{2}$ :

— Residential

\section{Spain}

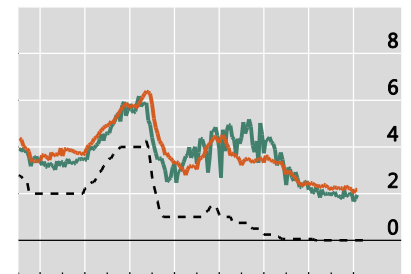

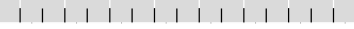
$\begin{array}{llllllll}04 & 06 & 08 & 10 & 12 & 14 & 16 & 18\end{array}$

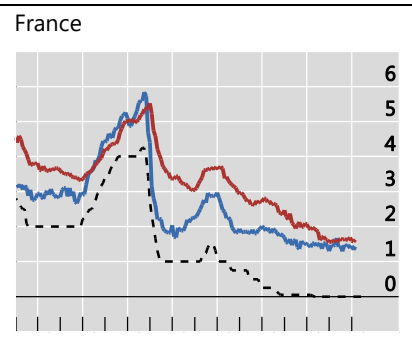

$\begin{array}{llllllll}04 & 06 & 08 & 10 & 12 & 14 & 16 & 18\end{array}$

Short-term lending rates ${ }^{1}$ :

- Non-financial corporations

United Kingdom

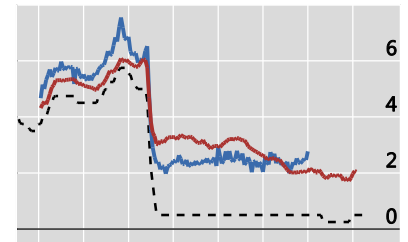

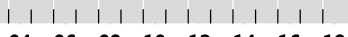

$\begin{array}{llllllll}04 & 06 & 08 & 10 & 12 & 14 & 16 & 18\end{array}$

France Italy

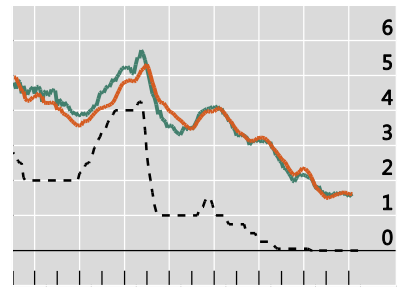

$\begin{array}{llllllll}04 & 06 & 08 & 10 & 12 & 14 & 16 & 18\end{array}$

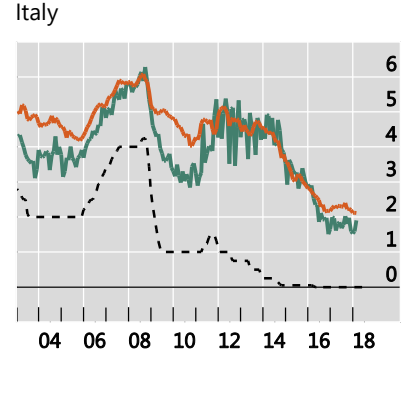

Long-term lending rates ${ }^{2}$

- Non-financial corporation

United Kingdom

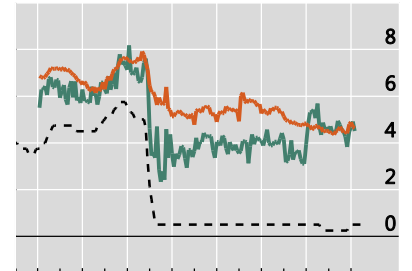

$\begin{array}{llllllll}04 & 06 & 08 & 10 & 12 & 14 & 16 & 18\end{array}$

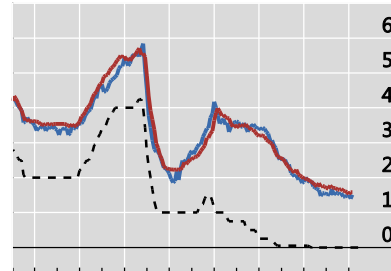

$\begin{array}{llllllll}04 & 06 & 08 & 10 & 12 & 14 & 16 & 18\end{array}$

- - - Policy rate

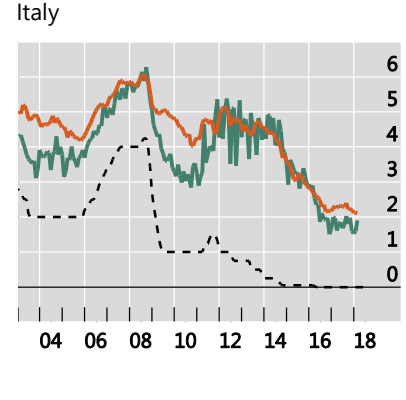
$\begin{array}{llllllll}04 & 06 & 08 & 10 & 12 & 14 & 16 & 18\end{array}$

1 The short-term is represented as less than 1-year maturity. 2 The long-term is represented as above 1-year maturity. The average maturity assumed for the long-term is 5 -year.

Sources: European Central Bank; national data.

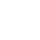

.




\section{Bank funding costs (WACL) and policy rates}

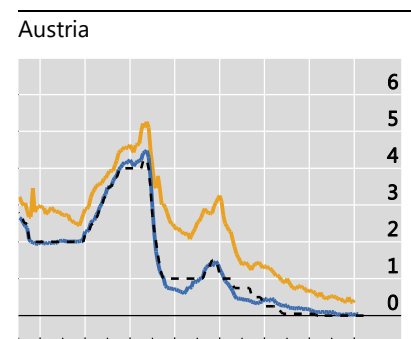

$\begin{array}{llllllllllllllll}\mid & 1 & \mid & 1 & \mid & 1 & 1 & 1 & 1 & 1 & 1 & 1 & 1 & 1 & 1 & 1\end{array}$ $\begin{array}{llllllll}04 & 06 & 08 & 10 & 12 & 14 & 16 & 18\end{array}$ - - - Policy rate

Germany

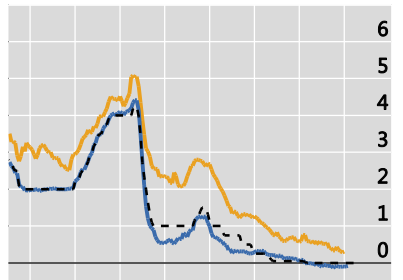

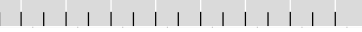
$\begin{array}{llllllll}04 & 06 & 08 & 10 & 12 & 14 & 16 & 18\end{array}$ Netherlands

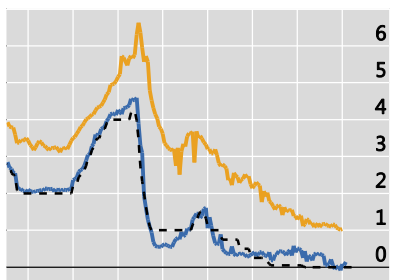

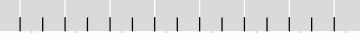
$\begin{array}{llllllll}04 & 06 & 08 & 10 & 12 & 14 & 16 & 18\end{array}$ Denmark

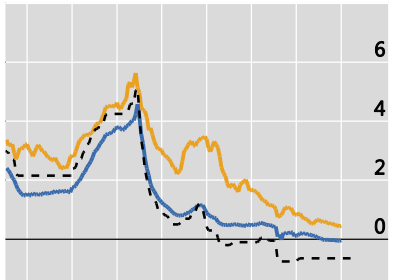

$\begin{array}{lllllllllllllll}\mid & \mid & \mid & \mid & \mid & \mid & \mid & \mid & \mid & \mid & \mid & \mid & \mid & 1 & \mid\end{array}$ $\begin{array}{llllllll}04 & 06 & 08 & 10 & 12 & 14 & 16 & 18\end{array}$

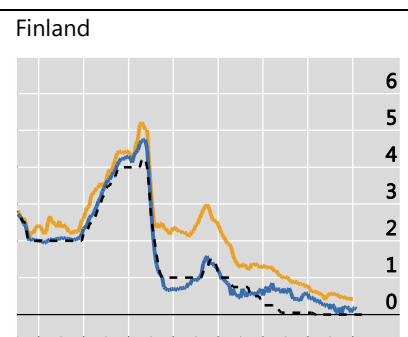

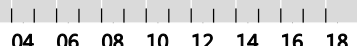

- MFI funding cost: short-term Ireland

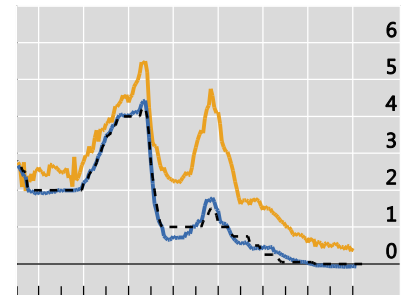

$\begin{array}{llllllll}04 & 06 & 08 & 10 & 12 & 14 & 16\end{array}$ Portugal

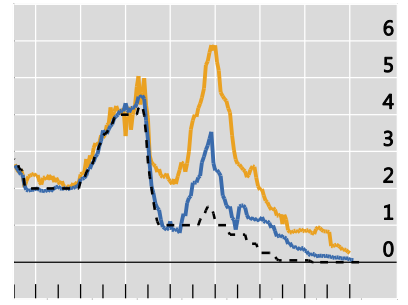

$\begin{array}{llllllll}04 & 06 & 08 & 10 & 12 & 14 & 16 & 18\end{array}$ United Kingdom
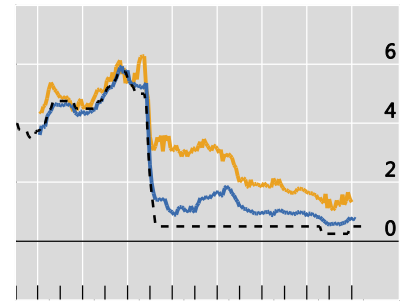

$\begin{array}{llllllll}04 & 06 & 08 & 10 & 12 & 14 & 16 & 18\end{array}$
France

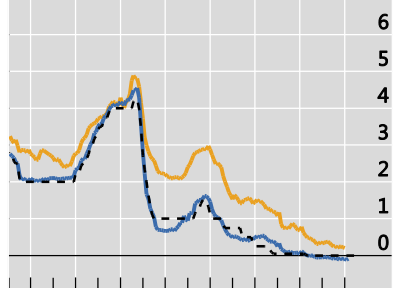

$\begin{array}{lllllllllll}04 & 06 & 08 & 10 & 12 & 14 & 16 & 18\end{array}$

- MF funding cost: long-term Italy
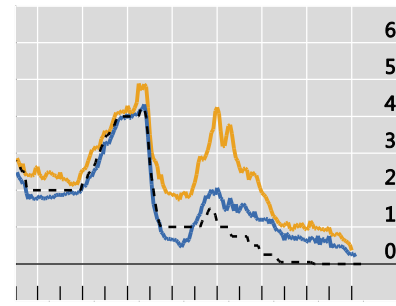

Spain

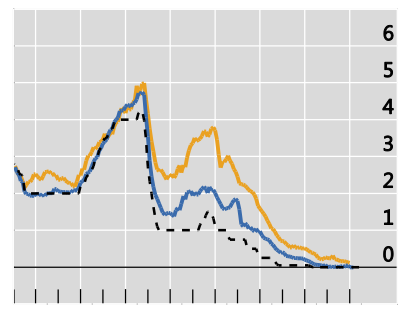

$\begin{array}{llllllll}04 & 06 & 08 & 10 & 12 & 14 & 16 & 18\end{array}$

1 The short-term represents less than 1-year maturity, while the long-term more than 1-year maturity assuming an average of 5-year. Sources: European Central Bank; Barclays; Dealogic; national data. 


\section{MFI lending rates and funding costs: short-term ${ }^{1}$}

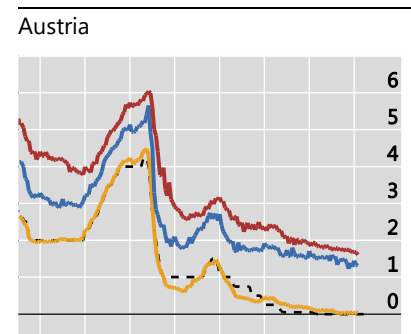

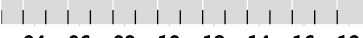
$\begin{array}{llllllll}04 & 06 & 08 & 10 & 12 & 14 & 16 & 18\end{array}$ Lending rates:

— Residential loans

Germany

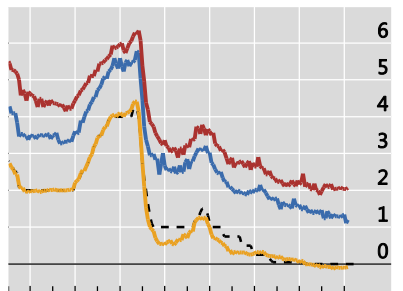

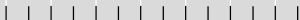
$\begin{array}{llllllll}04 & 06 & 08 & 10 & 12 & 14 & 16 & 18\end{array}$ - - - Policy rate

Netherlands

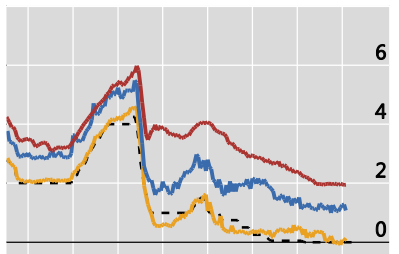

$\begin{array}{lllllllllllllll}1 & \mid & \mid & \mid & \mid & \mid & 1 & 1 & 1 & 1 & \mid & \mid & 1 & 1 & 1\end{array}$ $\begin{array}{llllllll}04 & 06 & 08 & 10 & 12 & 14 & 16 & 18\end{array}$ Denmark

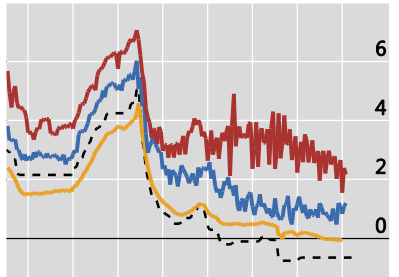

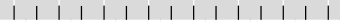

$\begin{array}{llllllll}04 & 06 & 08 & 10 & 12 & 14 & 16 & 18\end{array}$

The short-term is represented as less than $1-y$

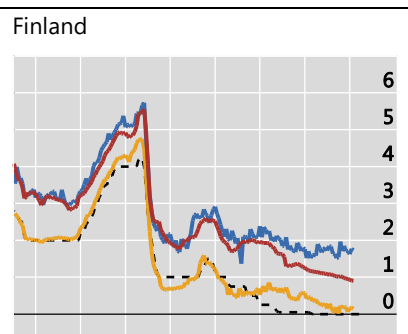

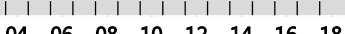
Lending rates:

Non-financial corporations loans Ireland

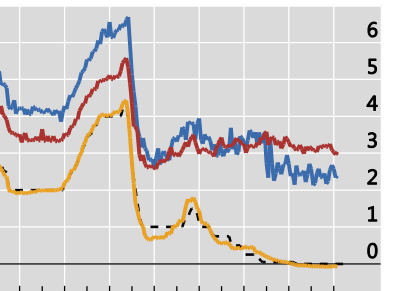

$\begin{array}{llllllll}04 & 06 & 08 & 10 & 12 & 14 & 16 & 18\end{array}$

Portugal

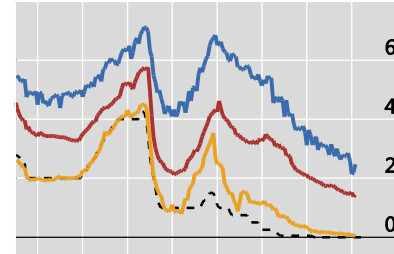

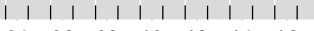
$\begin{array}{llllllll}04 & 06 & 08 & 10 & 12 & 14 & 16 & 18\end{array}$ United Kingdom
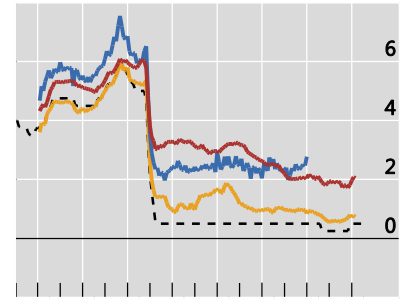

$\begin{array}{llllllll}04 & 06 & 08 & 10 & 12 & 14 & 16 & 18\end{array}$
France

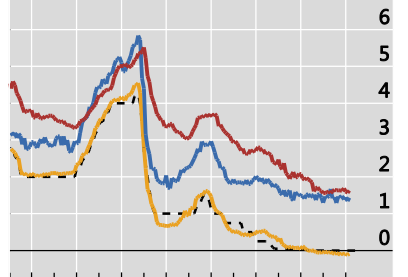

$\begin{array}{llllllllllllllllllll}04 & 06 & 08 & 10 & 12 & 14 & 16 & 18\end{array}$

- Bank funding cost

Italy

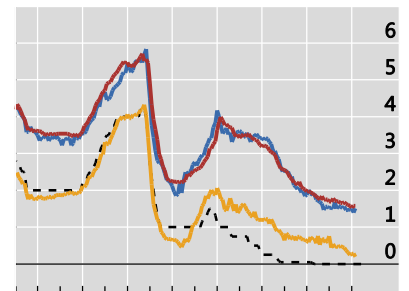

$\begin{array}{lllllllllll}\mid & 1 & 1 & 1 & \mid & \mid & 1 & 1 & 1 & 1\end{array}$ $\begin{array}{llllllll}04 & 06 & 08 & 10 & 12 & 14 & 16 & 18\end{array}$ - - - Policy rate

Spain

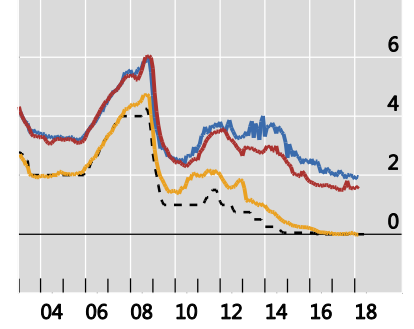

Sources: European Central Bank; national data. 
MFI lending rates and funding costs: long-term ${ }^{2}$

In per cent

Graph 4

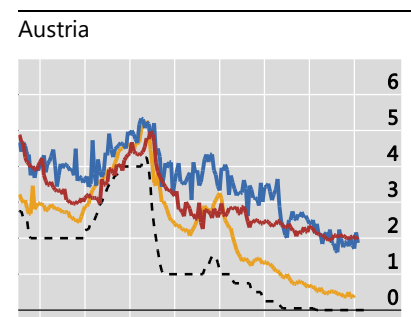

$\begin{array}{lllllllllllllll}1 & 1 & 1 & 1 & 1 & 1 & 1 & 1 & 1 & 1 & 1 & 1 & \mid & 1 & 1\end{array}$ $\begin{array}{llllllll}04 & 06 & 08 & 10 & 12 & 14 & 16 & 18\end{array}$ Lending rates:

- Residential loans

Germany

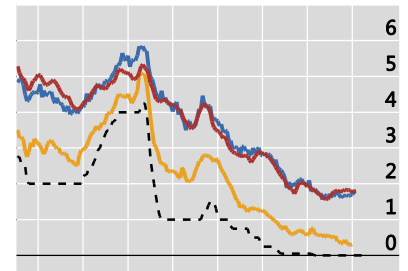

$\begin{array}{lllllllllllllll}1 & 1 & 1 & 1 & 1 & 1 & 1 & 1 & 1 & 1 & 1 & 1 & 1 & 1 & 1\end{array}$ $\begin{array}{llllllll}04 & 06 & 08 & 10 & 12 & 14 & 16 & 18\end{array}$ - - - Policy rate

Netherlands

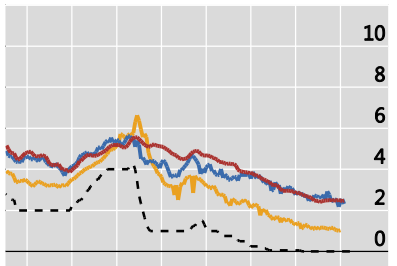

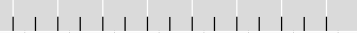
$\begin{array}{llllllll}04 & 06 & 08 & 10 & 12 & 14 & 16 & 18\end{array}$ Denmark
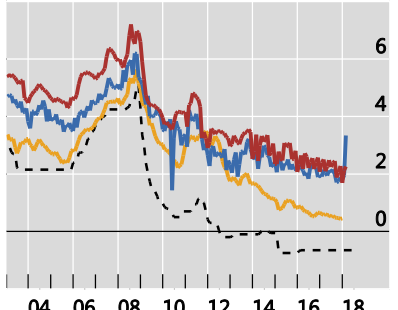

$\begin{array}{llllllll}04 & 06 & 08 & 10 & 12 & 14 & 16\end{array}$

Sources: European Central Bank; Barclays; Dealogic; national data. Lending rates: Ireland Portugal

\section{France}

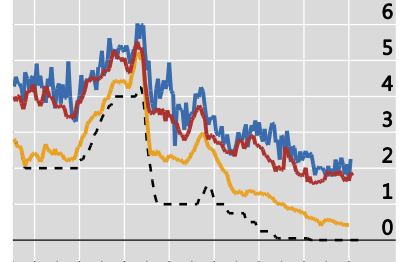

$\begin{array}{llllllllllllll}\mid & \mid & \mid & \mid & \mid & \mid & \mid & \mid & \mid & \mid & \mid & \mid & \mid & \mid \\ 04 & 06 & 08 & 10 & 12 & 14 & 16 & 18\end{array}$

- Non-financial corporations loans

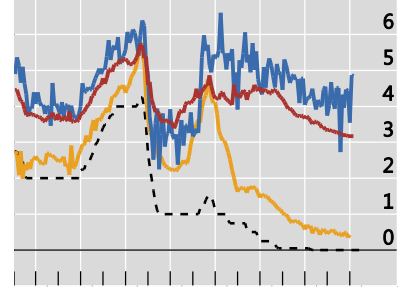
$\begin{array}{llllllll}04 & 06 & 08 & 10 & 12 & 14 & 16 & 18\end{array}$

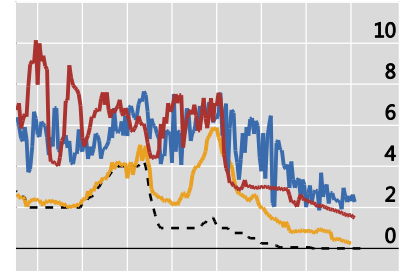
$\begin{array}{lllllllllllllll}\mid & \mid & \mid & \mid & \mid & \mid & \mid & \mid & \mid & \mid & \mid & \mid & \mid & \mid & \mid \\ 04 & 06 & 08 & 10 & 12 & 14 & 16 & 18\end{array}$ United Kingdom

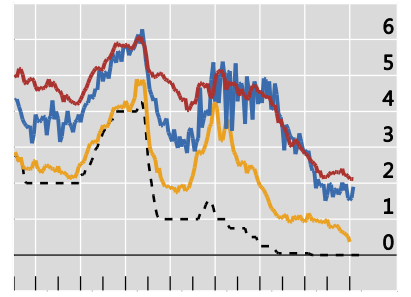
$\begin{array}{llllllll}04 & 06 & 08 & 10 & 12 & 14 & 16 & 18\end{array}$

Spain
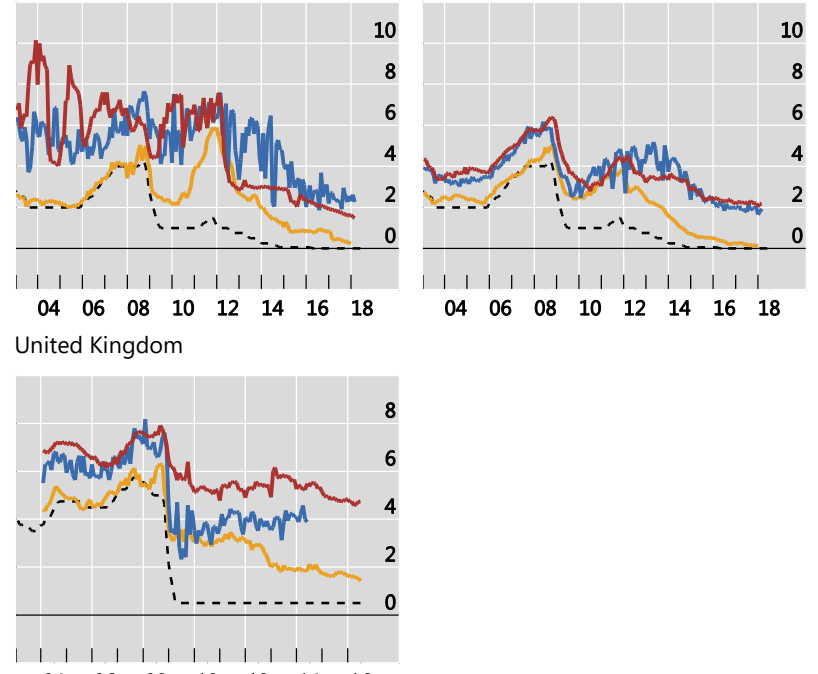

$1 / 1+1+1,1+1+1 / 2$ $\begin{array}{llllllll}04 & 06 & 08 & 10 & 12 & 14 & 16 & 18\end{array}$

- Bank funding cost

Italy
8

?


Bank funding costs respond strongly to "target" unconventional monetary policy shocks but more weakly to "path" shocks

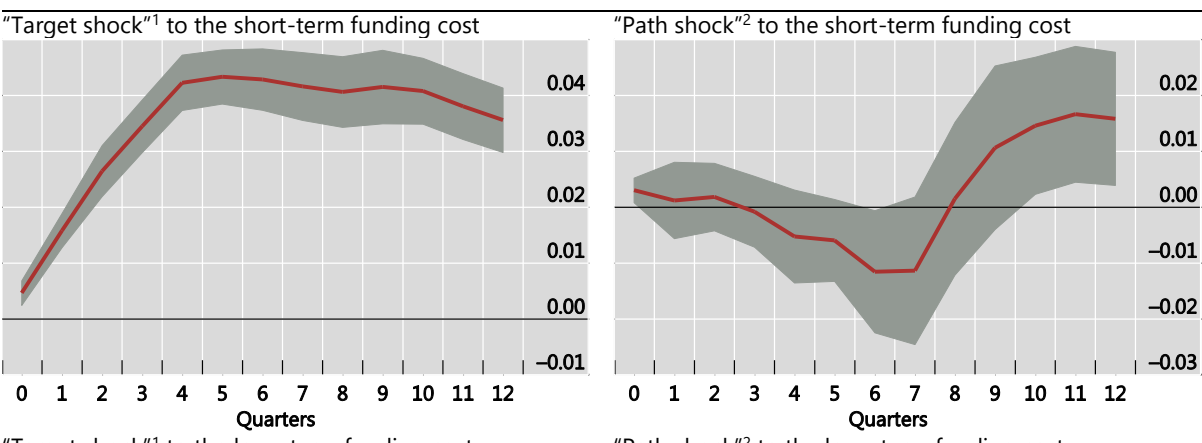

"Target shock"1 to the long-term funding cost

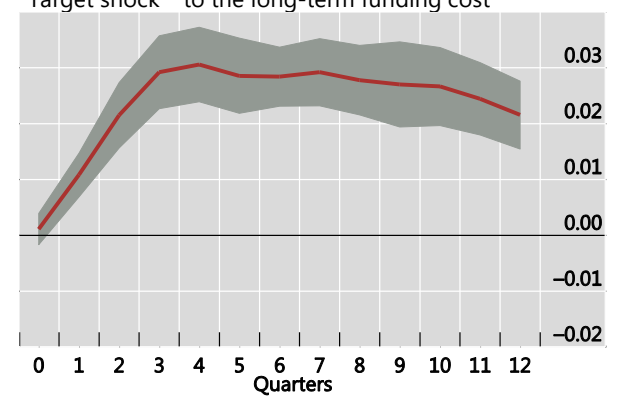

- Impulse response function

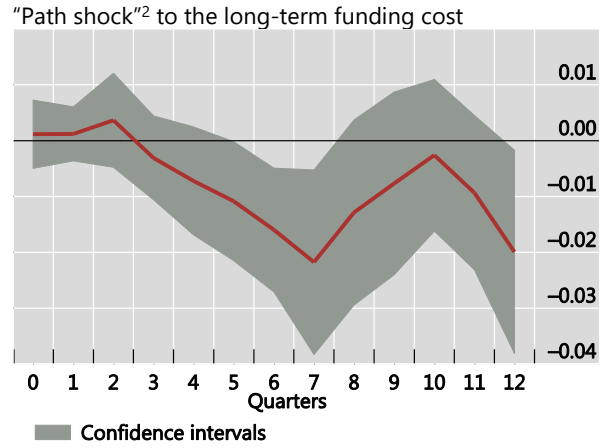

1 Change in the fixed rate on Overnight-Index Swaps (OIS) with a one month tenor. 2 Change in the spread between the 2-year sovereign bond yield and 1-month OIS rate.

Sources: BIS Working Papers No 626; authors' calculations. 
Lending rates respond significantly to a shock in the corresponding bank funding cost

Graph 6

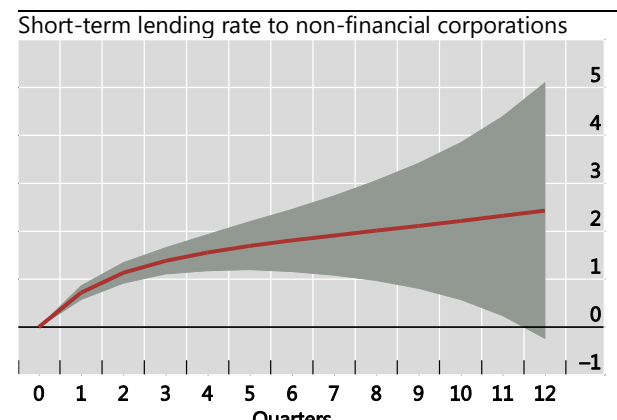

$\begin{array}{lllllllllllll}0 & 1 & 2 & 3 & 4 & 5 & 6 & 7 & 8 & 9 & 10 & 11 & 12 \\ \text { Quarters }\end{array}$

Long-term lending rate to non-financial corporations

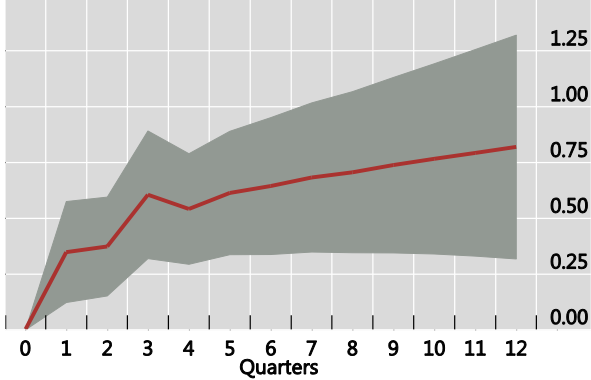

— Impulse response function

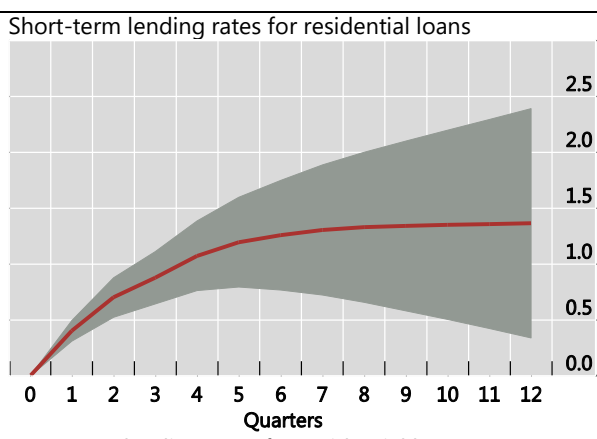

Long-term lending rates for residential loans

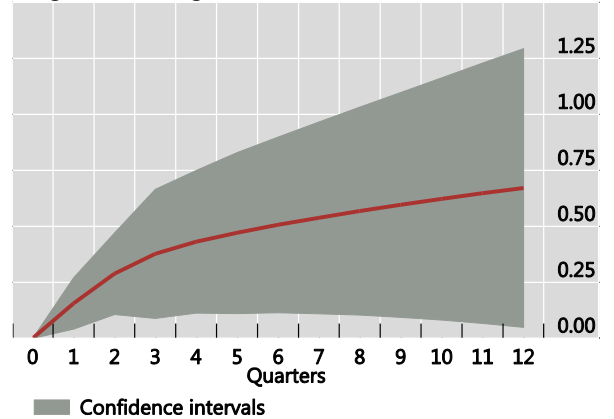

Source: Authors' calculations. 


\begin{tabular}{|c|c|c|c|c|c|}
\hline \multicolumn{5}{|l|}{ Unit root tests } & \multirow[t]{2}{*}{ Table 1} \\
\hline $\begin{array}{l}\text { Im-Pesaran-Shin } \\
\text { panel unit root test }\end{array}$ & & & & & \\
\hline Lending Rates & $\begin{array}{l}\text { Short rate to } \\
\text { NFCS }\end{array}$ & $\begin{array}{l}\text { Long rate to } \\
\text { NFCs }\end{array}$ & $\begin{array}{c}\text { Short } \\
\text { mortgage } \\
\text { rate }\end{array}$ & $\begin{array}{c}\text { Long } \\
\text { mortgage } \\
\text { rate }\end{array}$ & \\
\hline & $\begin{array}{c}2.226 \\
(0.987)\end{array}$ & $\begin{array}{c}0.415 \\
(0.661)\end{array}$ & $\begin{array}{l}0.995 \\
(0.840)\end{array}$ & $\begin{array}{c}2.644 \\
(0.996)\end{array}$ & \\
\hline \multirow[t]{2}{*}{$\begin{array}{c}\text { Bank funding costs } \\
\text { (short term) }\end{array}$} & $\begin{array}{l}\text { WACL(stock, } \\
\text { unadjusted) }\end{array}$ & $\begin{array}{l}\text { WACL (stock, } \\
\text { adjusted) }\end{array}$ & $\begin{array}{l}\text { WACL (flow, } \\
\text { adjusted) }\end{array}$ & & \\
\hline & $\begin{array}{c}1.315 \\
(0.906)\end{array}$ & $\begin{array}{c}1.315 \\
(0.906)\end{array}$ & $\begin{array}{l}1.895 \\
(0.971)\end{array}$ & & \\
\hline \multirow[t]{2}{*}{$\begin{array}{c}\text { Bank funding costs } \\
\text { (long term) }\end{array}$} & $\begin{array}{l}\text { WACL(stock, } \\
\text { unadjusted) }\end{array}$ & $\begin{array}{l}\text { WACL (stock, } \\
\text { adjusted) }\end{array}$ & $\begin{array}{l}\text { WACL (flow, } \\
\text { adjusted) }\end{array}$ & & \\
\hline & $\begin{array}{c}3.893 \\
(0.999)\end{array}$ & $\begin{array}{c}4.045 \\
(0.999)\end{array}$ & $\begin{array}{c}3.617 \\
(0.999)\end{array}$ & & \\
\hline \multirow[t]{2}{*}{ Policy rate } & Policy rate & & & & \\
\hline & $\begin{array}{c}1.791 \\
(0.963)\end{array}$ & & & & \\
\hline \multicolumn{6}{|l|}{$\begin{array}{l}\text { CIPS panel unit root } \\
\text { test }\end{array}$} \\
\hline \multirow[t]{2}{*}{ Lending Rates } & $\begin{array}{l}\text { Short rate to } \\
\text { NFCs }\end{array}$ & $\begin{array}{l}\text { Long rate to } \\
\text { NFCs }\end{array}$ & $\begin{array}{c}\text { Short } \\
\text { mortgage } \\
\text { rate }\end{array}$ & $\begin{array}{l}\text { Long } \\
\text { mortgage } \\
\text { rate }\end{array}$ & \\
\hline & -1.988 & $-2.835^{\star}$ & -1.923 & -2.470 & \\
\hline \multirow[t]{2}{*}{$\begin{array}{l}\text { Bank funding costs } \\
\text { (short term) }\end{array}$} & $\begin{array}{l}\text { WACL(stock, } \\
\text { unadjusted) }\end{array}$ & $\begin{array}{l}\text { WACL (stock, } \\
\text { adjusted) }\end{array}$ & $\begin{array}{l}\text { WACL (flow, } \\
\text { adjusted) }\end{array}$ & & \\
\hline & -1.622 & -1.622 & $-2.814^{\star}$ & & \\
\hline \multirow[t]{2}{*}{$\begin{array}{l}\text { Bank funding costs } \\
\text { (long term) }\end{array}$} & $\begin{array}{l}\text { WACL(stock, } \\
\text { unadjusted) }\end{array}$ & $\begin{array}{l}\text { WACL (stock, } \\
\text { adjusted) }\end{array}$ & $\begin{array}{l}\text { WACL (flow, } \\
\text { adjusted) }\end{array}$ & & \\
\hline & -2.453 & -2.282 & $-2.628^{\star}$ & & \\
\hline \multirow[t]{2}{*}{ Policy rate } & Policy rate & & & & \\
\hline & -0.420 & & & & \\
\hline
\end{tabular}

Notes: The top panel reports the W-statistic for the Im, Peseran and Shin (1999) test with p-value in brackets. The bottom pane reports the Pesaran (2007) CIPS test with t-statistic 


\begin{tabular}{|c|c|c|c|c|c|}
\hline Cointegration tests & & & & & Table 2 \\
\hline $\begin{array}{l}\text { Cointegration test allowing for } \\
\text { cross sectional dependence }\end{array}$ & $\begin{array}{l}\text { Persyn \& Westerlund } \\
\text { (2008) Test }\end{array}$ & $\begin{array}{l}\text { Short rate to } \\
\text { NFCs }\end{array}$ & $\begin{array}{l}\text { Long rate to } \\
\text { NFCs }\end{array}$ & $\begin{array}{l}\text { Short } \\
\text { mortgage } \\
\text { rate }\end{array}$ & $\begin{array}{l}\text { Long } \\
\text { mortgage } \\
\text { rate }\end{array}$ \\
\hline \multicolumn{6}{|l|}{ Policy Rate } \\
\hline Policy rate (full sample) & $G_{\tau}$ & $-3.030^{\star \star \star}$ & -0.985 & 0.182 & -1.072 \\
\hline Policy rate (full sample) & $P_{\tau}$ & -0.604 & $-2.212^{\star}$ & 0.156 & $-2.815^{\star \star \star}$ \\
\hline Policy rate (Pre-GFC sample) & $G_{\tau}$ & $-5.801^{\star \star \star}$ & $-3.375^{\star \star \star}$ & $-3.462^{\star \star \star}$ & -0.430 \\
\hline Policy rate (Pre-GFC sample) & $P_{\tau}$ & $-4.612^{\star \star \star}$ & $-5.241^{\star \star \star}$ & $-3.810^{\star \star \star}$ & $-4.283^{\star \star \star}$ \\
\hline \multicolumn{6}{|l|}{$\begin{array}{l}\text { Weighted Average Cost of } \\
\text { Liabilities (WACL) }\end{array}$} \\
\hline WACL (stock, unadjusted) & $G_{\tau}$ & $-3.023^{\star \star *}$ & $-2.331^{\star *}$ & $-2.186^{\star \star}$ & $-3.081^{* * *}$ \\
\hline WACL (stock, unadjusted) & $P_{\tau}$ & $-1.338^{\star}$ & $-4.366^{\star \star \star}$ & $-2.387^{\star \star \star}$ & $-2.106^{\star \star}$ \\
\hline WACL (stock adjusted) & $G_{\tau}$ & $-3.023^{* * *}$ & $-2.925^{\star \star *}$ & $-2.186^{\star *}$ & $-3.553^{\star * *}$ \\
\hline WACL (stock, adjusted) & $P_{\tau}$ & $-1.338^{*}$ & $-2.876^{\star \star \star}$ & $-2.387^{\star \star \star}$ & $-2.392^{\star \star \star}$ \\
\hline WACL (flow, adjusted) & $G_{\tau}$ & -0.431 & -1.272 & $-2.164^{\star \star}$ & $-2.611^{\star \star \star}$ \\
\hline WACL (flow, adjusted) & $P_{\tau}$ & 0.842 & $-2.868^{\star \star *}$ & $-1.964^{\star *}$ & $-2.558^{* * *}$ \\
\hline $\begin{array}{l}\text { Cointegration test allowing for } \\
\text { structural breaks and cross } \\
\text { sectional dependence }\end{array}$ & $\begin{array}{l}\text { Banerjee \& Carrion-i- } \\
\text { Sylvestre (2013) Test }\end{array}$ & $\begin{array}{c}\text { Short rate to } \\
\text { NFCs }\end{array}$ & $\begin{array}{l}\text { Long rate to } \\
\text { NFCs }\end{array}$ & $\begin{array}{l}\text { Short } \\
\text { mortgage } \\
\text { rate }\end{array}$ & $\begin{array}{l}\text { Long } \\
\text { mortgage } \\
\text { rate }\end{array}$ \\
\hline \multicolumn{6}{|l|}{ Policy Rate } \\
\hline $\begin{array}{l}\text { Policy rate (full sample, intercept } \\
\text { break) }\end{array}$ & $Z_{a}$ & -1.429 & -1.311 & $-2.882^{\star \star \star}$ & -0.193 \\
\hline $\begin{array}{l}\text { Policy rate (full sample, intercept } \\
\text { and cointegrating vector break) }\end{array}$ & $Z_{a c}$ & -0.592 & -0.468 & 0.448 & 1.834 \\
\hline \multicolumn{6}{|l|}{$\begin{array}{l}\text { Weighted Average Cost of } \\
\text { Liabilities (WACL) }\end{array}$} \\
\hline $\begin{array}{l}\text { WACL (stock, adjusted, full sample, } \\
\text { intercept break) }\end{array}$ & $Z_{a}$ & $-2.203^{\star \star}$ & $-2.355^{\star \star \star}$ & $-1.824^{*}$ & $-1.763^{*}$ \\
\hline $\begin{array}{l}\text { WACL (stock, adjusted full sample, } \\
\text { intercept and cointegrating vector } \\
\text { break) }\end{array}$ & $Z_{a c}$ & $-3.321^{\star \star *}$ & -1.208 & -0.954 & -0.526 \\
\hline
\end{tabular}

Note: The critical value for Persyn and Westerlund (2008) $G_{\tau}$ and $P_{\tau}$ tests at the $5 \%$ level is -1.96 and the critical value for Banerjee and Carrion-I-Silvestre (2013) $Z_{a}$ and $Z_{a c}$ tests is -1.96 . 
Pesaran-Shin-Smith pooled mean group estimates of interest rate pass-through using weighted average cost of liabilities (WACL)

Table 3

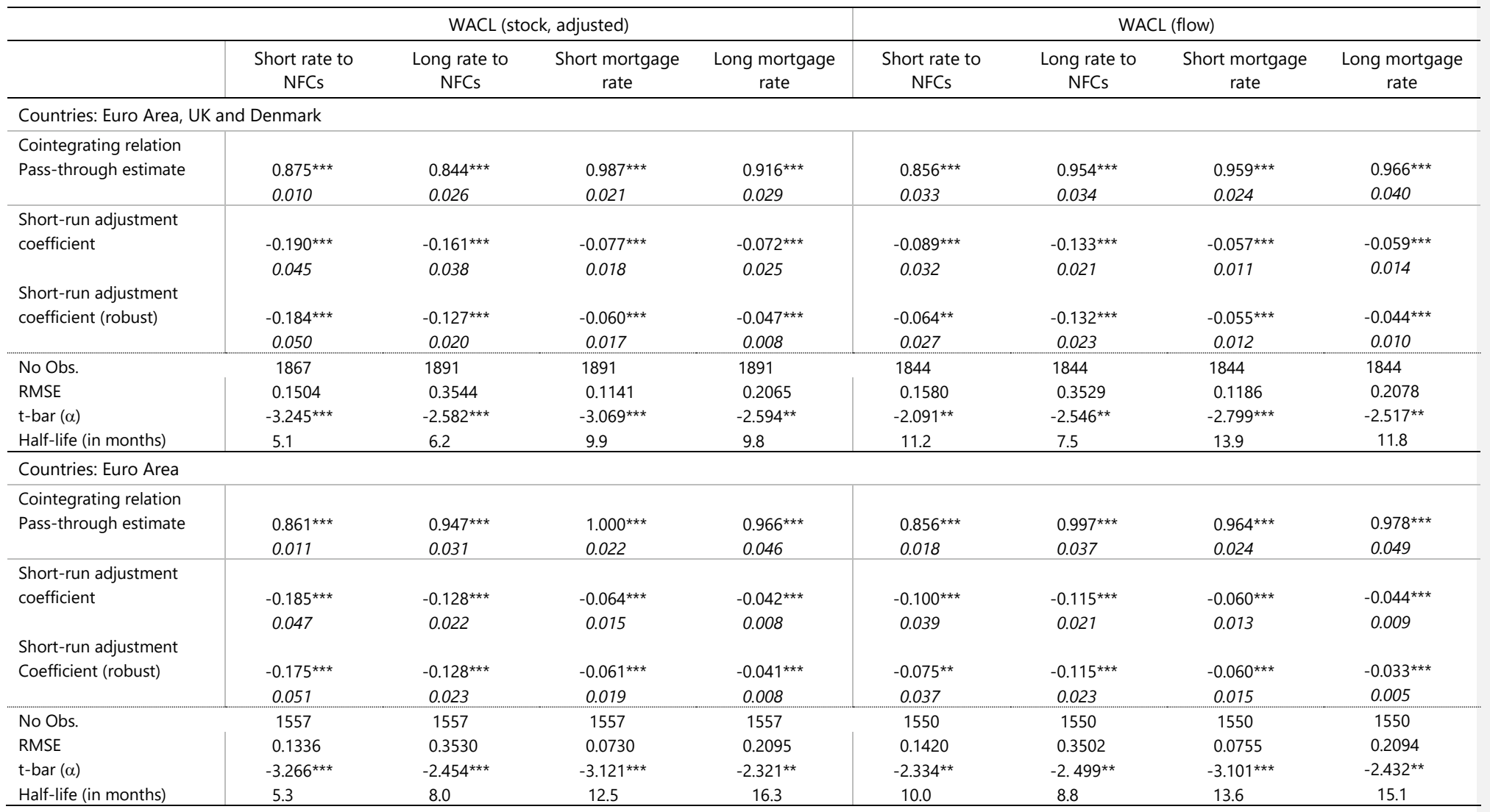


Countries: Euro Area Core

Cointegrating relation

Pass-through estimate

\begin{tabular}{|c|c|c|c|c|c|c|c|}
\hline $0.859^{* * *}$ & $0.940^{\star \star \star}$ & $1.001^{\star \star \star}$ & $0.966^{\star * *}$ & $0.847^{\star * *}$ & $0.993^{\star \star *}$ & $0.958^{\star \star \star}$ & $0.974^{\star \star \star}$ \\
\hline 0.011 & 0.032 & 0.024 & 0.051 & 0.019 & 0.039 & 0.027 & 0.053 \\
\hline$-0.259^{\star \star \star}$ & $-0.132^{* \star *}$ & $-0.084^{\star *}$ & $-0.041^{\star \star \star}$ & $-0.130^{* *}$ & $-0.103^{* \star *}$ & $-0.074^{* * *}$ & $-0.044^{\star \star \star}$ \\
\hline 0.064 & 0.032 & 0.022 & 0.011 & 0.069 & 0.028 & 0.019 & 0.010 \\
\hline$-0.257^{\star \star \star}$ & $-0.132^{\star \star *}$ & $-0.085^{\star \star \star}$ & -0.035 & $-0.129 * *$ & $-0.102^{\star \star \star}$ & $-0.075^{\star \star \star}$ & $-0.034^{* * *}$ \\
\hline 0.070 & 0.035 & 0.025 & 0.006 & 0.078 & 0.032 & 0.021 & 0.002 \\
\hline 865 & 865 & 865 & 865 & 862 & 862 & 862 & 862 \\
\hline 0.1174 & 0.1981 & 0.0688 & 0.0906 & 0.1286 & 0.1969 & 0.0699 & 0.0907 \\
\hline$-4.019^{\star \star *}$ & $-2.742^{\star * *}$ & $-3.817^{* \star *}$ & $-2.519^{* *}$ & $-2.323^{* \star *}$ & $-2.528^{\star *}$ & $-3.382^{* * *}$ & $-2.652^{\star *}$ \\
\hline 3.8 & 7.4 & 10.2 & 15.1 & 7.5 & 9.4 & 11.6 & 13.8 \\
\hline
\end{tabular}

Short-run adjustment

coefficient

Short-run adjustment

Coefficient (robust)

\section{No Obs.}

RMSE

$t-\operatorname{bar}(\alpha)$

Half-life (in months)

Notes: The pass-through estimate is obtained from the pooled $\theta$ estimate from equation (11), short-run adjustment coefficient is obtained from the pooled $\alpha_{i}$ estimate from equation (11). Standar

errors are given in italics beneath the coefficient estimates. The robust estimate ensures that the weight on each country is based on the proximity of the country observation to the average of all

countries, reducing the influence of outlier observations compared to the non-robust estimates. No.Obs is the total number of observations used to estimate the pooled mean group estimator. RMSE

is the root mean squared error of the regression. $t$-bar $(\alpha)$ is the unweighted average of the t-statistics on the short-run adjustment coefficient estimates $\left(\alpha_{i}\right)$. Half life is the time in months for a shock

to the equilibrium relation to decay by half. 
Pesaran-Shin-Smith pooled mean group estimates of interest rate pass-through using policy rates

Table 4

\begin{tabular}{|c|c|c|c|c|}
\hline & Short rate to NFCs & Long rate to NFCs & Short mortgage rate & Long mortgage rate \\
\hline \multicolumn{5}{|c|}{ Countries: Euro Area, UK and Denmark } \\
\hline \multicolumn{5}{|c|}{ Cointegrating relation } \\
\hline \multirow[t]{2}{*}{ Pass-through estimate } & $0.835^{\star \star *}$ & $0.907^{\star \star \star}$ & $0.973^{* * *}$ & 0.794 *** \\
\hline & 0.015 & 0.065 & 0.023 & 0.034 \\
\hline \multicolumn{5}{|l|}{ Short-run adjustment } \\
\hline \multirow[t]{2}{*}{ coefficient } & $-0.151^{\star \star \star}$ & $-0.073^{\star \star \star}$ & $-0.057^{\star \star \star}$ & -0.069 *** \\
\hline & 0.033 & 0.019 & 0.015 & 0.024 \\
\hline \multicolumn{5}{|l|}{ Short-run adjustment } \\
\hline \multirow[t]{2}{*}{ coefficient (robust) } & $-0.144^{\star \star \star}$ & $-0.062^{\star \star \star}$ & $-0.032^{* \star *}$ & $-0.032^{\star \star}$ \\
\hline & 0.034 & 0.015 & 0.007 & 0.013 \\
\hline No Obs. & 1867 & 1891 & 1900 & 1891 \\
\hline RMSE & 0.1534 & 0.3603 & 0.1181 & 0.2063 \\
\hline $\mathrm{t}-\operatorname{bar}(\alpha)$ & $-2.727^{\star \star \star}$ & -1.712 & $-2.585^{\star \star}$ & $-2.334^{\star \star}$ \\
\hline Half-life (in months) & 6.3 & 14.3 & 13.6 & 9.7 \\
\hline \multicolumn{5}{|l|}{ Countries: Euro Area } \\
\hline \multicolumn{5}{|l|}{ Cointegrating relation } \\
\hline \multirow[t]{2}{*}{ Pass-through estimate } & $0.907^{\star \star \star}$ & $0.991^{\star \star \star}$ & $0.976^{\star \star \star}$ & $0.965^{\star \star \star}$ \\
\hline & 0.020 & 0.076 & 0.023 & 0.075 \\
\hline \multicolumn{5}{|l|}{ Short-run adjustment } \\
\hline \multirow[t]{2}{*}{ coefficient } & $-0.123^{* * *}$ & $-0.068^{\star \star \star}$ & $-0.062^{* * *}$ & $-0.043^{* * *}$ \\
\hline & 0.028 & 0.020 & 0.018 & 0.012 \\
\hline \multicolumn{5}{|l|}{ Short-run adjustment } \\
\hline \multirow[t]{2}{*}{ coefficient (robust) } & $-0.123^{\star \star \star}$ & $-0.052^{\star \star \star}$ & $-0.034^{\star \star *}$ & -0.019 \\
\hline & 0.031 & 0.014 & 0.012 & 0.002 \\
\hline No Obs. & 1557 & 1557 & 1566 & 1557 \\
\hline RMSE & 0.1422 & 0.3598 & 0.0763 & 0.2084 \\
\hline $\mathrm{t}-\operatorname{bar}(\alpha)$ & $-2.566^{\star \star}$ & -1.795 & $-2.772^{\star \star *}$ & $-2.349^{\star *}$ \\
\hline Half-life (in months) & 7.9 & 15.4 & 12.3 & 15.1 \\
\hline \multicolumn{5}{|c|}{ Countries: Euro Area Core } \\
\hline \multicolumn{5}{|l|}{ Cointegrating relation } \\
\hline \multirow[t]{2}{*}{ Pass-through estimate } & $0.916^{\star \star \star}$ & $0.966^{\star \star \star}$ & $0.988^{\star \star \star}$ & $0.928^{\star \star \star}$ \\
\hline & 0.020 & 0.074 & 0.024 & 0.073 \\
\hline \multicolumn{5}{|l|}{ Short-run adjustment } \\
\hline \multirow[t]{2}{*}{ coefficient } & $-0.172^{\star \star \star}$ & $-0.090^{\star \star \star}$ & $-0.094^{\star \star \star}$ & $-0.048^{\star *}$ \\
\hline & 0.026 & 0.031 & 0.025 & 0.020 \\
\hline \multicolumn{5}{|l|}{ Short-run adjustment } \\
\hline \multirow[t]{2}{*}{ coefficient (robust) } & $-0.172^{\star \star \star}$ & $-0.060^{\star \star \star}$ & $-0.095^{\star *}$ & -0.048 \\
\hline & 0.029 & 0.013 & 0.028 & 0.021 \\
\hline No Obs. & 865 & 865 & 870 & 865 \\
\hline RMSE & 0.1285 & 0.2026 & 0.0713 & 0.0926 \\
\hline$t-\operatorname{bar}(\alpha)$ & $-3.273^{\star \star *}$ & $-2.494^{\star \star \star}$ & $-3.592^{\star \star \star}$ & $-2.686^{\star \star *}$ \\
\hline Half-life (in months) & 5.5 & 10.7 & 8.4 & 11.4 \\
\hline
\end{tabular}

Notes: See Table 3 


\begin{tabular}{|c|c|c|c|c|c|c|c|}
\hline \multicolumn{7}{|c|}{ Cointegration tests using the individual WACL components } & \multirow[t]{2}{*}{ Table 5} \\
\hline & \multicolumn{3}{|c|}{ Short-term } & \multicolumn{3}{|c|}{ Long-term } & \\
\hline & MFI deposits & Non-MFI deposits & $\begin{array}{l}\text { Short-term } \\
\text { securities }\end{array}$ & MFI deposits & Non-MFI deposits & $\begin{array}{l}\text { Covered } \\
\text { bonds }\end{array}$ & $\begin{array}{l}\text { Long-term } \\
\text { securities }\end{array}$ \\
\hline \multicolumn{8}{|l|}{ NFCs } \\
\hline \multicolumn{8}{|c|}{ Persyn \& Westerlund (2008) } \\
\hline$G_{\tau}$ & -0.109 & 1.440 & $-2.717^{* \star *}$ & $-1.546^{*}$ & $-2.073^{* *}$ & $-1.436^{\star}$ & $-1.808^{* *}$ \\
\hline$P_{\tau}$ & 1.222 & 0.687 & $-2.295^{* \star *}$ & $-2.783^{* \star *}$ & $-3.209^{* * *}$ & $-2.795^{* * *}$ & $-1.391^{*}$ \\
\hline \multicolumn{8}{|c|}{ Banerjee \& Carrion-i-Sylvestre (2013) } \\
\hline$Z_{\alpha}$ & $-3.147^{\star \star \star}$ & $-2.875^{\star \star \star}$ & $-3.121^{* \star *}$ & 0.303 & -1.612 & $-2.001^{\star *}$ & $-4.470^{* \star *}$ \\
\hline$Z_{\alpha c}$ & $-2.854^{\star \star \star}$ & -0.751 & $-2.666^{* \star *}$ & 0.586 & $-1.875^{\star}$ & $-1.888^{*}$ & $-4.075^{* * *}$ \\
\hline \multicolumn{8}{|c|}{ Mortgages } \\
\hline \multicolumn{8}{|c|}{ Persyn \& Westerlund (2008) } \\
\hline$G_{\tau}$ & $-2.405^{* *}$ & 0.356 & 0.061 & $-3.840^{* \star *}$ & $-2.528^{* *}$ & 0.392 & -0.216 \\
\hline$P_{T}$ & $-2.798^{\star \star \star}$ & 0.411 & $-1.351^{*}$ & $-3.350^{* \star *}$ & $-3.131^{* \star *}$ & $-2.006^{\star *}$ & -0.952 \\
\hline \multicolumn{8}{|c|}{ Banerjee \& Carrion-i-Sylvestre (2013) } \\
\hline$Z_{\alpha}$ & $-3.650^{\star \star *}$ & $-3.268^{* \star *}$ & $-2.673^{* \star *}$ & -0.310 & $-2.459^{* *}$ & -0.667 & $-4.236^{\star \star *}$ \\
\hline$Z_{\alpha c}$ & 0.425 & -0.740 & $-1.810^{\star}$ & $2.631^{* \star *}$ & $-1.831^{*}$ & -1.596 & $-3.860^{* \star *}$ \\
\hline
\end{tabular}


Pesaran-Shin-Smith pooled mean group estimates of interest rate pass-through using the individual WACL

\begin{tabular}{|c|c|c|c|c|c|c|c|}
\hline \multirow[t]{3}{*}{ components } & \multirow{2}{*}{\multicolumn{3}{|c|}{ Short-term }} & & & & Table \\
\hline & & & & \multicolumn{4}{|c|}{ Long-term } \\
\hline & MFI deposits & Non-MFI deposits & $\begin{array}{l}\text { Short-term } \\
\text { securities }\end{array}$ & MFI deposits & Non-MFI deposits & Covered bonds & $\begin{array}{l}\text { Long-term } \\
\text { securities }\end{array}$ \\
\hline \multicolumn{8}{|l|}{ NFCs } \\
\hline \multicolumn{8}{|l|}{ Cointegrating relation } \\
\hline Pass-through estimate & $\begin{array}{l}0.792^{* * \star} \\
0.011\end{array}$ & $\begin{array}{l}0.903^{* * *} \\
0.009\end{array}$ & $\begin{array}{l}0.703^{\star \star \star} \\
0.040\end{array}$ & $\begin{array}{l}0.735^{\star \star \star} \\
0.034\end{array}$ & $\begin{array}{l}1.006^{* \star \star} \\
0.039\end{array}$ & $\begin{array}{l}0.843^{* * *} \\
0.041\end{array}$ & $\begin{array}{l}0.758^{* * *} \\
0.060\end{array}$ \\
\hline $\begin{array}{l}\text { Short-run adjustment } \\
\text { coefficient }\end{array}$ & $\begin{array}{l}-0.151^{* * *} \\
0.045\end{array}$ & $\begin{array}{l}-0.216^{* \star \star} \\
0.055\end{array}$ & $\begin{array}{l}-0.045^{\star \star \star} \\
0.017\end{array}$ & $\begin{array}{l}-0.100^{\star \star \star} \\
0.030\end{array}$ & $\begin{array}{l}-0.114^{\star \star *} \\
0.020\end{array}$ & $\begin{array}{l}-0.070^{* \star *} \\
0.015\end{array}$ & $\begin{array}{l}-0.062^{\star \star \star} \\
0.019\end{array}$ \\
\hline $\begin{array}{l}\text { Short-run adjustment } \\
\text { coefficient (robust) }\end{array}$ & $\begin{array}{l}-0.110^{\star \star \star} \\
0.024\end{array}$ & $\begin{array}{l}-0.193^{* \star \star} \\
0.068\end{array}$ & $\begin{array}{l}-0.041^{* \star *} \\
0.017\end{array}$ & $\begin{array}{l}-0.063^{* *} \\
0.012\end{array}$ & $\begin{array}{l}-0.112^{\star * *} \\
0.022\end{array}$ & $\begin{array}{l}-0.068^{\star * \star} \\
0.016\end{array}$ & $\begin{array}{l}-0.049^{* * *} \\
0.018\end{array}$ \\
\hline No Obs. & 1867 & 1867 & 1867 & 1891 & 1891 & 1891 & 1891 \\
\hline RMSE & 0.1492 & 0.1552 & 0.1614 & 0.3574 & 0.3612 & 0.3611 & 0.3639 \\
\hline $\mathrm{t}-\operatorname{bar}(\alpha)$ & $-2.948^{\star * *}$ & $-3.918^{* \star *}$ & -1.484 & $-1.943^{*}$ & $-2.045^{* *}$ & $-1.928^{*}$ & -1.472 \\
\hline Half-life (in months) & 6.6 & 4.4 & 22.9 & 10.3 & 8.8 & 15.3 & 16.8 \\
\hline \multicolumn{8}{|l|}{ Mortgages } \\
\hline \multicolumn{8}{|l|}{ Cointegrating relation } \\
\hline Pass-through estimate & $\begin{array}{l}0.881^{* * *} \\
0.024\end{array}$ & $\begin{array}{l}1.003^{* * *} \\
0.024\end{array}$ & $\begin{array}{l}0.738^{* * *} \\
0.037\end{array}$ & $\begin{array}{l}0.817^{* * *} \\
0.035\end{array}$ & $\begin{array}{l}0.744^{* * \star} \\
0.047\end{array}$ & $\begin{array}{l}0.726^{* * *} \\
0.026\end{array}$ & $\begin{array}{l}0.752^{\star \star * \star} \\
0.045\end{array}$ \\
\hline $\begin{array}{l}\text { Short-run adjustment } \\
\text { coefficient }\end{array}$ & $\begin{array}{l}-0.051^{\star \star *} \\
0.013\end{array}$ & $\begin{array}{l}-0.086^{\star \star *} \\
0.030\end{array}$ & $\begin{array}{l}-0.030^{\star \star *} \\
0.009\end{array}$ & $\begin{array}{l}-0.061^{* * *} \\
0.020\end{array}$ & $\begin{array}{l}-0.052^{* \star *} \\
0.013\end{array}$ & $\begin{array}{l}-0.053^{* * *} \\
0.021\end{array}$ & $\begin{array}{l}-0.038^{\star \star \star} \\
0.013\end{array}$ \\
\hline Short-run adjustment & & & & & & & \\
\hline Coefficient (robust) & $\begin{array}{l}-0.039^{\star \star *} \\
0.015\end{array}$ & $\begin{array}{l}-0.057^{* * *} \\
0.012\end{array}$ & $\begin{array}{l}-0.021^{* * *} \\
0.010\end{array}$ & $\begin{array}{l}-0.037^{* *} \\
0.009\end{array}$ & $\begin{array}{l}-0.048^{* * *} \\
0.015\end{array}$ & $\begin{array}{l}-0.019^{\star \star \star} \\
0.003\end{array}$ & $\begin{array}{l}-0.014^{* * *} \\
0.002\end{array}$ \\
\hline No Obs. & 1891 & 1891 & 1891 & 1891 & 1891 & 1891 & 1891 \\
\hline RMSE & 0.1164 & 0.1115 & 0.1168 & 0.2048 & 0.2104 & 0.2031 & 0.2119 \\
\hline$t-\operatorname{bar}(\alpha)$ & $-2.522^{\star \star *}$ & $-3.135^{\star \star \star}$ & $-1.755^{*}$ & $-2.605^{\star *}$ & $-1.876^{*}$ & $-2.121^{\star *}$ & $-1.808^{*}$ \\
\hline Half-life (in months) & 14.9 & 8.8 & 26.4 & 11.4 & 13.4 & 13.2 & 18.3 \\
\hline
\end{tabular}


Pesaran-Shin-Smith pooled mean group estimates of interest rate passthrough using WACL for sub-samples (Euro area)

\begin{tabular}{|c|c|c|c|c|}
\hline & $\begin{array}{c}\text { Short rate to } \\
\text { NFCs }\end{array}$ & $\begin{array}{c}\text { Long rate to } \\
\text { NFCs }\end{array}$ & $\begin{array}{c}\text { Short mortgage } \\
\text { rate }\end{array}$ & $\begin{array}{l}\text { Long mortgage } \\
\text { rate }\end{array}$ \\
\hline \multicolumn{5}{|c|}{ Sample extends until global financial crisis (2003M1 - 2007M7) } \\
\hline \multicolumn{5}{|c|}{ Cointegrating relation } \\
\hline \multirow[t]{2}{*}{ Pass-through estimate } & $1.040 * \star \star$ & $1.182^{\star \star \star}$ & $1.000^{\star \star \star}$ & $0.949 * * *$ \\
\hline & 0.020 & 0.090 & 0.034 & 0.055 \\
\hline \multicolumn{5}{|l|}{ Short-run adjustment } \\
\hline \multirow[t]{2}{*}{ coefficient } & $-0.451^{\star \star \star}$ & $-0.294^{\star \star \star}$ & $-0.153^{\star \star \star}$ & $-0.167^{\star \star \star}$ \\
\hline & 0.103 & 0.077 & 0.035 & 0.072 \\
\hline \multicolumn{5}{|l|}{ Short-run adjustment } \\
\hline \multirow[t]{2}{*}{ coefficient (robust) } & $-0.389^{* \star \star}$ & $-0.299 * \star \star$ & $-0.152^{\star \star}$ & $-0.050^{\star \star \star}$ \\
\hline & 0.049 & 0.086 & 0.039 & 0.023 \\
\hline No Obs. & 432 & 432 & 432 & 432 \\
\hline RMSE & 0.0658 & 0.1914 & 0.0357 & 0.1307 \\
\hline $\mathrm{t}-\operatorname{bar}(\alpha)$ & $-2.694^{\star * *}$ & -1.509 & $-1.873^{*}$ & $-2.155^{\star \star}$ \\
\hline Half-life (in months) & 1.7 & 3.1 & 4.8 & 4.1 \\
\hline \multicolumn{5}{|c|}{ Sample extends until post crisis recession (2003M1 - 2008M8) } \\
\hline \multicolumn{5}{|c|}{ Cointegrating relation } \\
\hline \multirow[t]{2}{*}{ Pass-through estimate } & $0.950^{\star * *}$ & $0.894^{\star \star *}$ & $1.003^{\star \star *}$ & $0.789 * * *$ \\
\hline & 0.010 & 0.031 & 0.017 & 0.032 \\
\hline \multicolumn{5}{|l|}{ Short-run adjustment } \\
\hline \multirow[t]{2}{*}{ coefficient } & $-0.429 * * *$ & $-0.379^{* * *}$ & $-0.132^{\star \star *}$ & $-0.170^{\star * *}$ \\
\hline & 0.095 & 0.103 & 0.031 & 0.069 \\
\hline \multicolumn{5}{|l|}{ Short-run adjustment } \\
\hline \multirow[t]{2}{*}{ coefficient (robust) } & $-0.363^{* \star *}$ & $-0.385^{\star \star \star}$ & $-0.110^{\star \star \star}$ & $-0.138^{* *}$ \\
\hline & 0.093 & 0.119 & 0.030 & 0.063 \\
\hline No Obs. & 549 & 549 & 549 & 549 \\
\hline RMSE & 0.0764 & 0.2090 & 0.0420 & 0.1469 \\
\hline $\mathrm{t}-\operatorname{bar}(\alpha)$ & $-2.861^{\star \star \star}$ & $-1.930^{*}$ & $-2.459^{\star *}$ & $-2.262^{\star *}$ \\
\hline Half-life (in months) & 1.9 & 2.4 & 5.5 & 3.7 \\
\hline \multicolumn{5}{|c|}{ Sample extends until sovereign debt crisis (2003M1 - 2009M12) } \\
\hline \multicolumn{5}{|c|}{ Cointegrating relation } \\
\hline \multirow[t]{2}{*}{ Pass-through estimate } & $0.916^{\star * *}$ & $0.783^{* * *}$ & $0.811^{* * *}$ & $0.697^{* * *}$ \\
\hline & 0.010 & 0.025 & 0.015 & 0.023 \\
\hline \multicolumn{5}{|l|}{ Short-run adjustment } \\
\hline \multirow[t]{2}{*}{ coefficient } & $-0.434^{\star * *}$ & $-0.360^{\star \star *}$ & $-0.162^{\star \star \star}$ & $-0.167^{\star \star}$ \\
\hline & 0.066 & 0.078 & 0.050 & 0.066 \\
\hline \multicolumn{5}{|l|}{ Short-run adjustment } \\
\hline \multirow[t]{2}{*}{ coefficient (robust) } & $-0.426^{\star \star \star}$ & $-0.359^{\star \star *}$ & $-0.147^{\star \star \star}$ & $-0.104^{\star \star \star}$ \\
\hline & 0.072 & 0.085 & 0.049 & 0.035 \\
\hline No Obs. & 693 & 693 & 693 & 693 \\
\hline RMSE & 0.0941 & 0.2374 & 0.0536 & 0.1947 \\
\hline $\mathrm{t}-\mathrm{bar}(\alpha)$ & $-4.173^{\star \star \star}$ & $-2.596^{\star \star \star}$ & $-2.612^{\star \star \star}$ & $-2.735^{\star \star \star}$ \\
\hline Half-life (in months) & 2.0 & 2.4 & 5.1 & 3.6 \\
\hline
\end{tabular}

Notes: See Table 3 
Appendix

WACL Stock Measure

The following measures of outstanding volumes were recorded:

Deposit liabilities (in all currencies, and excluding the general government) vis-à-vis the euro area to MFIs and to non-MFIs, obtained from the ECB, which reports the MFIs aggregate balance sheet on a national basis (excluding the ESCB). For non euro area countries we use sources from national central banks.

Debt securities, issued in all currencies in the euro area by the MFIs. This is obtained from the MFIs balance sheets, which also report breakdowns of maturities up to and over one year.

Covered bonds, which are obtained from Dealogic. This component is only used for the long-term calculations, as we assume that all of the covered bonds have a maturity of more than one year.

Funding from central bank operations. We only use this for the euro area countries. Liquidity provided by the central bank is a component that became important in the period after 2009. For the short-term, we include the amounts of the Main Refinancing Operations (MROs), while for the long-term we sum up the amounts of MROs and the long-term refinancing operations (LTROs).

\section{WACL Flow Measure}

The following items of flows were recorded:

New deposits with agreed maturity for non-MFIs from the ECB record the deposit flows. Since there is no new deposits data for the MFIs, we approximated this by multiplying the flow data of the nonMFIs with the ratio between the outstanding amounts of interbank and private deposit liabilities.

Data on debt securities is obtained from the ECB debt securities database, which reports the gross issuance by sector of securities other than shares for the short- (less than one year) and the longterm (more than one year).

The covered bonds gross issuance is obtained from Dealogic, which reports the gross issuance by the financial sector; this is used only in the long-term calculation.

\section{Weight Adjustments}

We assume that banks will use cheapest available funding, unless constrained, and will not borrow at rates above lending rates of the same maturity. At some points the cost of issuing debt securities exceeds the lending rate, therefore, we impose the condition that in this case securities will be funded by less expensive covered bonds rather than conventional bonds, which will be zero weighted. This produces an adjusted WACL.

Funding from the central bank is often the cheapest available form of funding, but banks will not always borrow from this source rather than from depositors or bond holders if they are constrained by the availability of collateral. 
Weight components of the short-term WACL ${ }^{1}$

In per cent

Table A1

\begin{tabular}{|c|c|c|c|c|c|c|c|c|c|c|c|c|}
\hline & \multicolumn{3}{|c|}{ MFI deposits } & \multicolumn{3}{|c|}{ Non-MFI deposits } & \multicolumn{3}{|c|}{$\begin{array}{l}\text { Short-term securities } \\
\text { other than shares }\end{array}$} & \multicolumn{3}{|c|}{$\begin{array}{l}\text { Central bank } \\
\text { operations }^{2}\end{array}$} \\
\hline & All & Pre & Post & All & Pre & Post & All & Pre & Post & All & Pre & Post \\
\hline Austria & 37.9 & 38.8 & 37.4 & 60.3 & 58.6 & 61.3 & 1.0 & 1.1 & 0.9 & 0.8 & 1.5 & 0.4 \\
\hline Finland & 18.6 & 17.7 & 19.1 & 70.6 & 67.3 & 72.6 & 10.4 & 14.0 & 8.2 & 0.4 & 1.0 & 0.0 \\
\hline France & 46.5 & 47.2 & 46.1 & 46.0 & 44.2 & 47.1 & 7.4 & 8.6 & 6.7 & 0.0 & 0.0 & 0.1 \\
\hline Germany & 33.7 & 38.7 & 30.7 & 64.0 & 57.2 & 68.1 & 0.9 & 1.1 & 0.7 & 1.4 & 2.9 & 0.4 \\
\hline Ireland & 50.7 & 53.7 & 49.0 & 44.4 & 40.0 & 47.0 & 2.9 & 4.5 & 1.9 & 2.0 & 1.8 & 2.1 \\
\hline Italy & 36.6 & 40.5 & 34.3 & 62.6 & 58.4 & 65.0 & 0.1 & 0.0 & 0.1 & 0.7 & 1.1 & 0.5 \\
\hline Netherlands & 20.5 & 29.2 & 15.3 & 76.9 & 68.5 & 81.9 & 2.6 & 2.3 & 2.8 & & & \\
\hline Portugal & 28.2 & 31.5 & 26.3 & 70.2 & 68.3 & 71.3 & 0.3 & 0.1 & 0.5 & 1.3 & 0.1 & 1.9 \\
\hline Spain & 24.9 & 25.9 & 24.3 & 72.0 & 69.4 & 73.5 & 2.0 & 3.2 & 1.3 & 1.1 & 1.5 & 0.8 \\
\hline Denmark & 35.2 & 30.2 & 38.1 & 64.0 & 69.1 & 61.0 & 0.8 & 0.7 & 0.9 & & & \\
\hline $\begin{array}{l}\text { United } \\
\text { Kingdom }\end{array}$ & 27.9 & 36.4 & 22.9 & 66.6 & 57.5 & 72.1 & 5.5 & 6.2 & 5.1 & & & \\
\hline
\end{tabular}

1 All refers to all of the sample, pre-crisis is from January 2003 (depending on data availability) to August 2008; post-crisis is from September 2008 to the latest data available. 2 ECB main refinancing operations.

Sources: European Central Bank; national data.

Weight components of the long-term WACL ${ }^{1}$

In per cent

Table A2

\begin{tabular}{|c|c|c|c|c|c|c|c|c|c|c|c|c|c|c|c|}
\hline & \multicolumn{3}{|c|}{ MFI deposits } & \multicolumn{3}{|c|}{ Non-MFI deposits } & \multicolumn{3}{|c|}{$\begin{array}{l}\text { Long-term } \\
\text { securities other } \\
\text { than shares }\end{array}$} & \multicolumn{3}{|c|}{ Covered bonds } & \multicolumn{3}{|c|}{$\begin{array}{c}\text { Central bank } \\
\text { operations }^{2}\end{array}$} \\
\hline & All & Pre & Post & All & Pre & Post & All & Pre & Post & All & Pre & Post & All & Pre & Post \\
\hline Austria & 26.6 & 27.1 & 26.3 & 42.3 & 40.9 & 43.2 & 27.0 & 29.0 & 25.8 & 2.5 & 1.5 & 3.1 & 1.6 & 1.5 & 1.6 \\
\hline Finland & 15.0 & 16.9 & 13.9 & 57.5 & 64.1 & 53.5 & 20.8 & 16.3 & 23.6 & 5.4 & 1.2 & 7.9 & 1.2 & 1.5 & 1.0 \\
\hline France & 39.5 & 41.9 & 38.1 & 39.0 & 39.3 & 38.8 & 16.2 & 15.5 & 16.7 & 4.6 & 3.4 & 5.3 & 0.7 & 0.0 & 1.1 \\
\hline Germany & 23.3 & 24.0 & 22.9 & 45.1 & 35.5 & 50.9 & 20.9 & 23.4 & 19.4 & 8.8 & 14.3 & 5.4 & 1.9 & 2.8 & 1.4 \\
\hline Ireland & 40.0 & 42.5 & 38.4 & 35.1 & 32.0 & 37.0 & 13.3 & 16.0 & 11.7 & 5.5 & 5.7 & 5.3 & 6.2 & 3.8 & 7.6 \\
\hline Italy & 26.2 & 29.7 & 24.1 & 44.6 & 42.9 & 45.7 & 24.7 & 26.3 & 23.7 & 1.3 & 0.2 & 1.9 & 3.2 & 0.8 & 4.6 \\
\hline Netherlands & 14.8 & 21.9 & 10.5 & 53.9 & 50.7 & 55.8 & 25.7 & 24.6 & 26.3 & 1.8 & 0.6 & 2.5 & 3.9 & 2.1 & 4.9 \\
\hline Portugal & 22.3 & 27.5 & 19.1 & 55.0 & 59.6 & 52.1 & 13.9 & 10.9 & 15.8 & 3.7 & 0.8 & 5.5 & 5.1 & 1.2 & 7.5 \\
\hline Spain & 19.4 & 21.5 & 18.1 & 55.9 & 57.1 & 55.1 & 10.9 & 11.4 & 10.6 & 9.9 & 8.5 & 10.7 & 4.0 & 1.5 & 5.5 \\
\hline Denmark & 13.6 & 11.7 & 14.7 & 24.6 & 26.5 & 23.4 & 60.3 & 61.7 & 59.5 & 1.5 & 0.0 & 2.4 & & & \\
\hline $\begin{array}{l}\text { United } \\
\text { Kingdom }\end{array}$ & 25.0 & 33.5 & 19.8 & 58.6 & 52.8 & 62.2 & 13.9 & 12.9 & 14.5 & 2.5 & 0.8 & 3.5 & & & \\
\hline
\end{tabular}

1 All refers to all of the sample, pre-crisis is from January 2003 (depending on data availability) to August 2008; post-crisis is from September 2008 to the latest data available. 2 ECB main refinancing operations and long-term refinancing operations.

Sources: European Central Bank; Dealogic; national data. 


\section{Interest rate components of the short-term $\mathrm{WACL}^{1}$}

In per cent

Table A3

\begin{tabular}{|c|c|c|c|c|c|c|c|c|c|c|c|c|}
\hline & \multicolumn{3}{|c|}{ MFI deposits ${ }^{2}$} & \multicolumn{3}{|c|}{ Non-MFI deposits ${ }^{3}$} & \multicolumn{3}{|c|}{$\begin{array}{l}\text { Short-term securities } \\
\text { other than shares }\end{array}$} & \multicolumn{3}{|c|}{$\begin{array}{l}\text { Central bank } \\
\text { operations }^{5}\end{array}$} \\
\hline & All & Pre & Post & All & Pre & Post & All & Pre & Post & All & Pre & Post \\
\hline Austria & 1.21 & 2.80 & 0.28 & 1.57 & 2.77 & 0.86 & 2.31 & 3.33 & 1.72 & 1.42 & 2.73 & 0.65 \\
\hline Finland & 1.21 & 2.80 & 0.28 & 1.58 & 2.80 & 0.84 & 2.07 & 3.32 & 1.35 & 1.42 & 2.73 & 0.65 \\
\hline France & 1.21 & 2.80 & 0.28 & 1.63 & 2.81 & 0.93 & 2.04 & 3.29 & 1.30 & 1.42 & 2.73 & 0.65 \\
\hline Germany & 1.21 & 2.80 & 0.28 & 1.41 & 2.73 & 0.62 & 2.09 & 3.35 & 1.36 & 1.42 & 2.73 & 0.65 \\
\hline Ireland & 1.21 & 2.80 & 0.28 & 1.59 & 2.62 & 0.97 & 4.50 & 3.36 & 5.17 & 1.42 & 2.73 & 0.65 \\
\hline Italy & 1.21 & 2.80 & 0.28 & 1.88 & 2.47 & 1.52 & 2.72 & 3.31 & 2.38 & 1.42 & 2.73 & 0.65 \\
\hline Netherlands & 1.21 & 2.80 & 0.28 & 1.52 & 2.87 & 0.72 & 2.80 & 3.81 & 2.20 & 1.42 & 2.73 & 0.65 \\
\hline Portugal & 1.21 & 2.80 & 0.28 & 2.00 & 2.74 & 1.56 & 4.08 & 3.33 & 4.53 & 1.42 & 2.73 & 0.65 \\
\hline Spain & 1.21 & 2.80 & 0.28 & 1.93 & 2.80 & 1.41 & 2.86 & 3.35 & 2.58 & 1.42 & 2.73 & 0.65 \\
\hline Denmark & 1.29 & 2.89 & 0.35 & 1.43 & 2.11 & 1.01 & 2.23 & 3.41 & 1.54 & 1.24 & 2.96 & 0.25 \\
\hline $\begin{array}{l}\text { United } \\
\text { Kingdom }\end{array}$ & 2.12 & 4.70 & 0.61 & 2.44 & 4.65 & 1.36 & 2.94 & 5.12 & 1.66 & 2.07 & 4.64 & 0.59 \\
\hline
\end{tabular}

Interest rate components of the long-term $\mathrm{WACL}^{1}$

In per cent

Table A4

\begin{tabular}{|c|c|c|c|c|c|c|c|c|c|c|c|c|c|c|c|}
\hline & \multicolumn{3}{|c|}{ MFI deposits ${ }^{2}$} & \multicolumn{3}{|c|}{ Non-MFI deposits 3} & \multicolumn{3}{|c|}{$\begin{array}{l}\text { Long-term } \\
\text { securities other } \\
\text { than shares }{ }^{4}\end{array}$} & \multicolumn{3}{|c|}{ Covered bonds } & \multicolumn{3}{|c|}{$\begin{array}{l}\text { Central bank } \\
\text { operations }{ }^{5}\end{array}$} \\
\hline & All & Pre & Post & All & Pre & Post & All & Pre & Post & All & Pre & Post & All & Pre & Post \\
\hline Austria & 1.78 & 3.20 & 0.92 & 2.11 & 3.15 & 1.48 & 3.36 & 4.02 & 2.96 & 2.46 & 4.02 & 1.52 & 1.46 & 2.75 & 0.68 \\
\hline Finland & 1.78 & 3.20 & 0.92 & 2.07 & 2.97 & 1.53 & 2.99 & 3.95 & 2.40 & 2.18 & 3.62 & 1.30 & 1.46 & 2.75 & 0.68 \\
\hline France & 1.78 & 3.20 & 0.92 & 2.41 & 3.02 & 2.04 & 3.04 & 3.93 & 2.51 & 2.44 & 3.74 & 1.65 & 1.46 & 2.75 & 0.68 \\
\hline Germany & 1.78 & 3.20 & 0.92 & 2.26 & 3.33 & 1.61 & 3.13 & 4.04 & 2.57 & 2.06 & 3.54 & 1.16 & 1.46 & 2.75 & 0.68 \\
\hline Ireland & 1.78 & 3.20 & 0.92 & 2.44 & 2.92 & 2.15 & 5.05 & 4.07 & 5.64 & 3.17 & 3.71 & 2.85 & 1.46 & 2.75 & 0.68 \\
\hline Italy & 1.78 & 3.20 & 0.92 & 2.00 & 2.35 & 1.79 & 3.76 & 3.97 & 3.63 & 3.02 & 4.20 & 2.31 & 1.46 & 2.75 & 0.68 \\
\hline Netherlands & 1.78 & 3.20 & 0.92 & 3.34 & 4.22 & 2.81 & 3.72 & 4.38 & 3.31 & 2.48 & 3.80 & 1.68 & 1.46 & 2.75 & 0.68 \\
\hline Portugal & 1.78 & 3.20 & 0.92 & 2.20 & 2.56 & 1.98 & 4.94 & 4.03 & 5.49 & 3.79 & 4.40 & 3.42 & 1.46 & 2.75 & 0.68 \\
\hline Spain & 1.78 & 3.20 & 0.92 & 2.10 & 2.70 & 1.74 & 3.91 & 4.01 & 3.84 & 3.33 & 4.01 & 2.92 & 1.46 & 2.75 & 0.68 \\
\hline Denmark & 2.03 & 3.33 & 1.24 & 1.43 & 2.11 & 1.01 & 3.20 & 4.04 & 2.69 & 2.24 & 3.36 & 1.55 & 1.30 & 2.96 & 0.29 \\
\hline $\begin{array}{l}\text { United } \\
\text { Kingdom }\end{array}$ & 2.74 & 5.06 & 1.34 & 3.38 & 4.95 & 2.60 & 3.90 & 5.28 & 3.06 & 2.71 & 4.05 & 1.90 & 2.13 & 4.64 & 0.60 \\
\hline \multicolumn{16}{|c|}{$\begin{array}{l}\text { All refers to all the sample, pre-crisis is from January } 2003 \text { (depending on data availability) to August 2008; post-crisis is from September } 2008 \\
\text { to end-2017. } 2 \text { Interbank } 12 \text {-month rates. }{ }^{3} \text { Deposit rate on euro deposits with agreed maturity for the non-financial corporations and } \\
\text { households with maturities over } 1 \text { year, if data not available, close approximation to this rate. }{ }^{4} \text { The } 5 \text {-year interest rate swap plus the } 5 \text {-year } \\
\text { financial CDS for selected banks in each country. }{ }^{5} \text { Central bank policy rate. }\end{array}$} \\
\hline
\end{tabular}


